Article

\title{
Phyto-Functionalized Silver Nanoparticles Derived from Conifer Bark Extracts and Evaluation of Their Antimicrobial and Cytogenotoxic Effects
}

\author{
Irina Macovei ${ }^{1}$, Simon Vlad Luca ${ }^{1,2}$, Krystyna Skalicka-Woźniak ${ }^{3}{ }^{\mathbb{D}}$, Liviu Sacarescu ${ }^{4}$, Petronela Pascariu ${ }^{4}$, \\ Alina Ghilan ${ }^{4}$, Florica Doroftei ${ }^{4}$, Elena-Laura Ursu ${ }^{4}$, Cristina Mihaela Rimbu ${ }^{5, *}$, Cristina Elena Horhogea ${ }^{5}$, \\ Cristina Lungu ${ }^{1}$, Gabriela Vochita ${ }^{6}$, Alina Diana Panainte ${ }^{1}$, Constantin Nechita ${ }^{7}$ (D), Maria Andreia Corciova ${ }^{1}$ \\ and Anca Miron 1,*
}

check for

updates

Citation: Macovei, I.; Luca, S.V.; Skalicka-Woźniak, K.; Sacarescu, L.; Pascariu, P.; Ghilan, A.; Doroftei, F.; Ursu, E.-L.; Rimbu, C.M.; Horhogea, C.E.; et al. Phyto-Functionalized Silver Nanoparticles Derived from Conifer Bark Extracts and Evaluation of Their Antimicrobial and Cytogenotoxic Effects. Molecules 2022, 27, 217. https://doi.org/10.3390/ molecules 27010217

Academic Editor: Rita Cortesi

Received: 6 December 2021

Accepted: 27 December 2021

Published: 30 December 2021

Publisher's Note: MDPI stays neutral with regard to jurisdictional claims in published maps and institutional affiliations.

Copyright: (c) 2021 by the authors. Licensee MDPI, Basel, Switzerland. This article is an open access article distributed under the terms and conditions of the Creative Commons Attribution (CC BY) license (https:// creativecommons.org/licenses/by/ $4.0 /)$.
1 Faculty of Pharmacy, Grigore T. Popa University of Medicine and Pharmacy, 700115 Iasi, Romania; irina-macovei@umfiasi.ro (I.M.); lungu.cristina@umfiasi.ro (C.L.); alina.gudruman@umfiasi.ro (A.D.P.); maria.corciova@umfiasi.ro (M.A.C.)

2 Biothermodynamics, TUM School of Life Sciences, Technical University of Munich, D-85354 Freising, Germany; vlad.luca@tum.de

3 Department of Natural Products Chemistry, Medical University of Lublin, 20-093 Lublin, Poland; kskalicka@pharmacognosy.org

4 Petru Poni Institute of Macromolecular Chemistry, 700487 Iasi, Romania; livius@icmpp.ro (L.S.); dorneanu.petronela@icmpp.ro (P.P.); diaconu.alina@icmpp.ro (A.G.); florica.doroftei@icmpp.ro (F.D.); ursu.laura@icmpp.ro (E.-L.U.)

5 Department of Public Health, Ion Ionescu de la Brad University of Agricultural Sciences and Veterinary Medicine, 700489 Iasi, Romania; chorhogea@uaiasi.ro

6 NIRDBS, Institute of Biological Research, 700107 Iasi, Romania; gabriela.vochita@icbiasi.ro

7 Marin Dracea National Institute for Research and Development in Forestry, 725100 Campulung Moldovenesc, Romania; ncincds@gmail.com

* Correspondence: crimbu@yahoo.com (C.M.R.); anca.miron@umfiasi.ro (A.M.)

\begin{abstract}
Silver nanoparticles synthesized using plant extracts as reducing and capping agents showed various biological activities. In the present study, colloidal silver nanoparticle solutions were produced from the aqueous extracts of Picea abies and Pinus nigra bark. The phenolic profile of bark extracts was analyzed by liquid chromatography coupled to mass spectrometry. The synthesis of silver nanoparticles was monitored using UV-Vis spectroscopy by measuring the Surface Plasmon Resonance band. Silver nanoparticles were characterized by attenuated total reflection Fourier transform infrared spectroscopy, Raman spectroscopy, dynamic light scattering, scanning electron microscopy, energy dispersive X-ray and transmission electron microscopy analyses. The antimicrobial and cytogenotoxic effects of silver nanoparticles were evaluated by disk diffusion and Allium cepa assays, respectively. Picea abies and Pinus nigra bark extract derived silver nanoparticles were spherical (mean hydrodynamic diameters of 78.48 and $77.66 \mathrm{~nm}$, respectively) and well dispersed, having a narrow particle size distribution (polydispersity index values of 0.334 and 0.224 , respectively) and good stability (zeta potential values of -10.8 and $-14.6 \mathrm{mV}$, respectively). Silver nanoparticles showed stronger antibacterial, antifungal, and antimitotic effects than the bark extracts used for their synthesis. Silver nanoparticles obtained in the present study are promising candidates for the development of novel formulations with various therapeutic applications.
\end{abstract}

Keywords: silver nanoparticles; green synthesis; Picea abies bark; Pinus nigra bark; polyphenols; antimicrobial activity; antimitotic activity; genotoxicity

\section{Introduction}

Silver nanoparticles (AgNPs) are characterized by being at least one dimension smaller than $100 \mathrm{~nm}$ and having a high surface area to volume ratio. Due to their remarkable antimicrobial effects, good optical properties, low thermal and electrical resistance, AgNPs have 
applications in various sectors such as healthcare, food industry, environmental health, electronics, instrumental analysis, and catalysis [1]. AgNPs can be produced by physical (evaporation and condensation, laser ablation, spray pyrolysis), chemical (chemical reduction, electromagnetic radiation, and electrochemical cell methods), biological (plant extract and microbial reduction) and mechanical (ball milling) methods [1,2]. Both physical and chemical methods have several drawbacks, such as high energy consumption, expensive equipment, long reaction time, use of toxic chemicals and generation of chemical wastes (unreacted chemicals) which have to be discarded [1]. In recent years, biological methods (green synthesis), using either plant extracts or living microorganisms, have gained increased attention as they are simple, rapid, and cost-effective [1,2]. The use of plant extracts is more advantageous for several reasons. First, plants are easily available and inexpensive. Second, in contrast to the aforementioned methods, plant extract mediated synthesis of AgNPs generates waste which is not harmful for the environment. In addition, plant extracts contain various phytochemicals which can act as reducing and/or capping agents in AgNPs synthesis [3]. Phytochemicals in plant extracts are able to reduce Ag ions to Ag atoms and, moreover, to form an outer shell around nanosized metallic Ag, thus averting the aggregation of nanoparticles and stabilizing them [4]. Plant extracts act not only as reducing and/or capping agents, but also as modulators of the biological effects of nanosized metallic Ag [5]. Thus, AgNPs synthesized using plant extracts or pure phytochemicals have been reported to develop a wide range of biological activities, such as antibacterial, antifungal and antiviral [6], anti-inflammatory [7], antioxidant [5,7], wound healing [8], anticancer [1,3], anticoagulant [9], cardioprotective [10], liver protective [10], antidiabetic [11], anti-cataractogenic [12] and anti-ageing [13] activities.

Conifer bark is one of the best candidates for AgNPs synthesis. It contains various biologically active compounds such as polyphenols (phenolic acids, flavonoids, proanthocyanidins, stilbenes, lignans), terpenoids, sterols, carbohydrates which act as reducing and/or stabilizing agents in AgNPs synthesis [14]. Proanthocyanidins (condensed tannins), major components in conifer bark, are oligomers and polymers of flavan-3-ol units. There are several types of proanthocyanidins depending on the monomer. Procyanidins, prodelphinidins and propelargonidins are the most common, the monomer being (epi)catechin, (epi)gallocatechin and (epi)afzelechin, respectively [15]. Proanthocyanidins from conifer bark have been reported to develop antioxidant, anti-inflammatory, immunomodulatory, anticancer, and hypoglycemic effects. They also have positive effects on the cardiovascular (vasorelaxation, activation of microcirculation, strengthening of capillaries, reduction of blood pressure and atherosclerotic lesions) and nervous (neuroprotection) systems $[14,16]$. The main stilbenes identified in conifer bark are pinosylvin, piceatannol, trans-resveratrol, isorhapontigenin and pinostilbene along with their glycosides (astringin, resveratroloside, piceid, isorhapontin, pinostilbenoside) [14]. Known as phytoalexins (usually produced by plants in response to pathogen attack, UV, or ozone exposure, cold, drought), stilbenes display a broad spectrum of biological activities (antimicrobial, antioxidant, anti-inflammatory, chemopreventive, lipolytic). Numerous studies support their role in the protection against cardiovascular and neurodegenerative disorders and cancer $[14,17,18]$. Conifer bark contains a wide range of flavonoids, quercetin, kaempferol, naringenin, eriodictyol and their derivatives being the most common ones [14]. Flavonoids are undoubtedly the class of plant metabolites having the most numerous health benefits. Among flavonoids found in conifer bark, taxifolin (dihydroquercetin) has gained great interest due to its excellent anti-inflammatory, antioxidant and vasoprotective activities which provide beneficial effects in various diseases (cardiovascular, liver, skin and cognitive disorders, malignancies) [19]. Overall, the use of conifer bark extracts in AgNPs synthesis might result in phyto-functionalized AgNPs with promising therapeutic applications.

Although conifer bark is a rich source of compounds having reducing abilities and exerting a broad range of bioactivities, its potential application in the green synthesis of AgNPs has been scarcely investigated [20,21]. In this context, the present study was initiated; the study reports on the green synthesis of colloidal AgNPs solutions using aqueous 
extracts derived from the bark of two conifer species, Picea abies (L.) H. Karst. (Norway spruce) and Pinus nigra J. F. Arnold (black pine). The aqueous colloidal AgNPs solutions were further subjected to physicochemical characterization by various spectroscopic and microscopic methods. Their antimicrobial, antimitotic and genotoxic effects were also evaluated.

\section{Results and Discussion}

\subsection{Phenolic Content and Profile of Conifer Bark Extracts}

In this study, aqueous bark extracts of two conifers, namely Picea abies and Pinus nigra, were used as reducing and stabilizing agents to synthesize AgNPs. Conifer bark is a rich source of phenolic compounds with very diverse chemical structures [14]. According to previous reports, phenolic compounds play a major role in the formation and stabilization of AgNPs, acting as reducing and stabilizing agents [4,5,22,23]. Compounds having at least two phenolic hydroxyl groups (ortho or para position) efficiently reduce Ag ions to Ag atoms, the phenolic hydroxyls being oxidized into quinones; the quinone-type molecules cover the surface of AgNPs, thus enhancing their stability [4,23]. Other functional groups in polyphenols, such as the carboxyl moieties of phenolic acids, might also interact with Ag surface contributing to the stabilization of AgNPs [23]. Therefore, the first objective of the present study was to investigate the quantitative and qualitative phenolic composition of aqueous extracts derived from Picea abies and Pinus nigra bark. Picea abies bark extract showed higher contents of total phenolics (10.19 \pm 0.15 vs. $4.51 \pm 0.34 \mathrm{mg}$ gallic acid $/ \mathrm{mL}$ extract) and proanthocyanidins (5.06 \pm 0.49 vs. $0.95 \pm 0.05 \mathrm{mg}$ cyanidin $/ \mathrm{mL}$ extract) than Pinus nigra bark extract. The phenolic profiles of bark extracts are illustrated in Figure 1. High-performance liquid chromatography with diode array detection coupled to electrospray ionization quadrupole time-of-flight tandem mass spectrometry (HPLC-DADESI-Q-TOF-MS/MS) revealed 24 compounds in Picea abies bark extract and 17 compounds in Pinus nigra bark extract. Simple phenolics, benzoic acid derivatives, hydroxycinnamic acid derivatives and other phenylpropanoids, flavonoids, proanthocyanidins (procyanidin oligomers) and stilbenes were tentatively identified by comparing their spectral data with those reported in databases (METLIN, KNApSacK, PubChem, NIST Chemistry WebBook) or literature (Table 1).

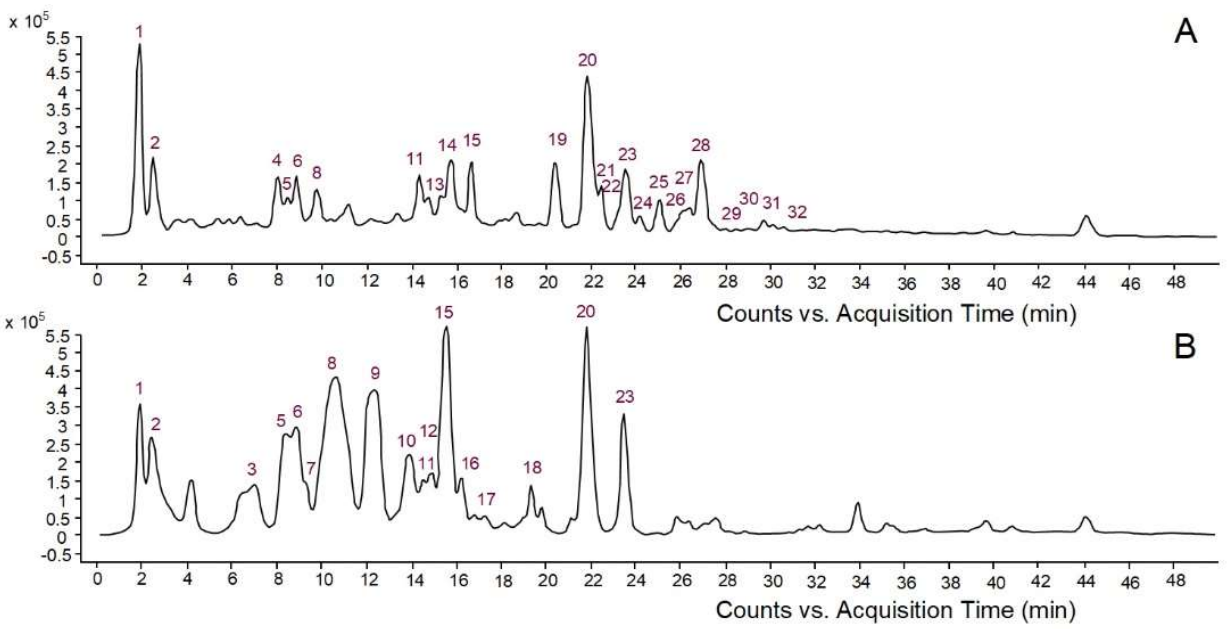

Figure 1. Base peak chromatograms of Picea abies (A) and Pinus nigra (B) aqueous bark extracts. 
Table 1. Compounds tentatively identified in Picea abies and Pinus nigra aqueous bark extracts.

\begin{tabular}{|c|c|c|c|c|c|c|c|}
\hline No. & $\begin{array}{c}\mathrm{T}_{\mathrm{R}} \\
{[\mathrm{min}]}\end{array}$ & $\begin{array}{c}{[\mathbf{M}-\mathbf{H}]^{-}} \\
{[m / z]}\end{array}$ & MF & $\begin{array}{l}\text { MS/MS Fragments } \\
{[m / z]}\end{array}$ & $\begin{array}{l}\text { Proposed } \\
\text { Identity }\end{array}$ & Sample & Ref. \\
\hline 1 & 1.9 & 191.0561 & $\mathrm{C}_{7} \mathrm{H}_{12} \mathrm{O}_{6}$ & $173.0437 ; 127.0442$ & Quinic acid & $\begin{array}{l}\text { Picea abies } \\
\text { Pinus nigra }\end{array}$ & [24] \\
\hline 2 & 2.5 & 191.0204 & $\mathrm{C}_{6} \mathrm{H}_{8} \mathrm{O}_{7}$ & $129.0237 ; 111.0126$ & Citric acid & $\begin{array}{l}\text { Picea abies } \\
\text { Pinus nigra }\end{array}$ & [24] \\
\hline 3 & 7.0 & 329.0830 & $\mathrm{C}_{14} \mathrm{H}_{18} \mathrm{O}_{9}$ & $\begin{array}{c}167.0425 ; 152.0186 \\
123.0506\end{array}$ & $\begin{array}{c}\text { Vanillic acid } \\
\text { hexoside }\end{array}$ & Pinus nigra & [25] \\
\hline 4 & 8.1 & 345.1533 & $\mathrm{C}_{16} \mathrm{H}_{26} \mathrm{O}_{8}$ & $183.0293 ; 139.0322$ & $\begin{array}{c}\text { Methoxy- } \\
\text { dihydroxybenzoic acid hexoside }\end{array}$ & Picea abies & [26] \\
\hline 5 & 8.5 & 299.0832 & $\mathrm{C}_{13} \mathrm{H}_{16} \mathrm{O}_{8}$ & 137.0284 & Hydroxybenzoic acid hexoside & $\begin{array}{l}\text { Pinus nigra } \\
\text { Picea abies }\end{array}$ & [24] \\
\hline 6 & 8.9 & 315.0995 & $\mathrm{C}_{14} \mathrm{H}_{20} \mathrm{O}_{8}$ & 153.0553; 109.0301 & Dimethoxyphenyl hexoside & $\begin{array}{l}\text { Picea abies } \\
\text { Pinus nigra }\end{array}$ & [27] \\
\hline 7 & 9.4 & 313.0919 & $\mathrm{C}_{14} \mathrm{H}_{18} \mathrm{O}_{8}$ & 151.0433 & Vanillin hexoside & Pinus nigra & [28] \\
\hline 8 & 9.8 & 137.0257 & $\mathrm{C}_{7} \mathrm{H}_{6} \mathrm{O}_{3}$ & 109.0245 & Hydroxybenzoic acid & $\begin{array}{l}\text { Picea abies } \\
\text { Pinus nigra }\end{array}$ & {$[24,25]$} \\
\hline 9 & 12.5 & 343.1385 & $\mathrm{C}_{16} \mathrm{H}_{24} \mathrm{O}_{8}$ & 181.1133 & $\begin{array}{c}\text { Dihydro- } \\
\text { coniferylalcohol hexoside I }\end{array}$ & Pinus nigra & {$[29,30]$} \\
\hline 10 & 14.0 & 337.0939 & $\mathrm{C}_{16} \mathrm{H}_{18} \mathrm{O}_{8}$ & $\begin{array}{c}\text { 191.0561; } 163.0430 \\
119.0516\end{array}$ & $p$-Coumaroylquinic acid & Pinus nigra & [31] \\
\hline 11 & 14.4 & 577.1331 & $\mathrm{C}_{30} \mathrm{H}_{26} \mathrm{O}_{12}$ & $\begin{array}{l}\text { 451.1057; 425.0931; } \\
\text { 407.0825; 289.0747; } \\
245.0451 ; 125.0268\end{array}$ & $\begin{array}{l}\text { Procyanidin } \\
\text { dimer }\end{array}$ & $\begin{array}{l}\text { Picea abies } \\
\text { Pinus nigra }\end{array}$ & {$[32,33]$} \\
\hline 12 & 14.6 & 465.1025 & $\mathrm{C}_{21} \mathrm{H}_{22} \mathrm{O}_{12}$ & $\begin{array}{l}303.0651 ; 285.0537 \\
259.0775 ; 125.0363\end{array}$ & $\begin{array}{l}\text { Taxifolin } \\
\text { hexoside I }\end{array}$ & Pinus nigra & {$[32,34]$} \\
\hline 13 & 14.8 & 355.1050 & $\mathrm{C}_{16} \mathrm{H}_{20} \mathrm{O}_{9}$ & $\begin{array}{c}193.0604 ; 178.0266 \\
149.0626\end{array}$ & $\begin{array}{l}\text { Ferulic acid } \\
\text { hexoside }\end{array}$ & Picea abies & {$[35,36]$} \\
\hline 14 & 15.3 & 327.1058 & $\mathrm{C}_{15} \mathrm{H}_{20} \mathrm{O}_{8}$ & 165.0553 & $\begin{array}{c}\text { Dihydroxy } \\
\text { propiophenone } \\
\text { hexoside }\end{array}$ & Picea abies & [37] \\
\hline 15 & 15.8 & 289.0778 & $\mathrm{C}_{15} \mathrm{H}_{14} \mathrm{O}_{6}$ & $\begin{array}{l}\text { 271.0678; 245.0727; } \\
\text { 205.0661; } 151.0330\end{array}$ & Catechin * & $\begin{array}{l}\text { Picea abies } \\
\text { Pinus nigra }\end{array}$ & {$[25,32]$} \\
\hline 16 & 16.3 & 343.1388 & $\mathrm{C}_{16} \mathrm{H}_{24} \mathrm{O}_{8}$ & 181.1149 & $\begin{array}{c}\text { Dihydro } \\
\text { coniferylalcohol hexoside II }\end{array}$ & Pinus nigra & {$[29,30]$} \\
\hline 17 & 17.3 & 865.1959 & $\mathrm{C}_{45} \mathrm{H}_{38} \mathrm{O}_{18}$ & $\begin{array}{l}\text { 577.1237; } 407.0348 \\
289.0753\end{array}$ & $\begin{array}{l}\text { Procyanidin } \\
\text { trimer }\end{array}$ & Pinus nigra & {$[24,32]$} \\
\hline 18 & 19.4 & 289.0765 & $\mathrm{C}_{15} \mathrm{H}_{14} \mathrm{O}_{6}$ & $\begin{array}{l}\text { 271.0666; 245.0733; } \\
\text { 205.0654; } 151.0311\end{array}$ & Epicatechin * & Pinus nigra & {$[24,25]$} \\
\hline 19 & 20.5 & 405.1172 & $\mathrm{C}_{20} \mathrm{H}_{22} \mathrm{O}_{9}$ & $\begin{array}{c}243.0723 ; 201.0586 \\
159.0482\end{array}$ & $\begin{array}{l}\text { Piceatannol } \\
\text { hexoside I }\end{array}$ & Picea abies & [38] \\
\hline 20 & 21.9 & 465.1025 & $\mathrm{C}_{21} \mathrm{H}_{22} \mathrm{O}_{12}$ & $\begin{array}{l}303.0638 ; 285.0539 \\
259.0749 ; 125.0313\end{array}$ & $\begin{array}{l}\text { Taxifolin } \\
\text { hexoside II }\end{array}$ & $\begin{array}{l}\text { Picea abies } \\
\text { Pinus nigra }\end{array}$ & {$[32,34]$} \\
\hline 21 & 22.5 & 405.1169 & $\mathrm{C}_{20} \mathrm{H}_{22} \mathrm{O}_{9}$ & $\begin{array}{c}243.0733 ; 201.0533 \\
159.0466\end{array}$ & $\begin{array}{l}\text { Piceatannol } \\
\text { hexoside II }\end{array}$ & Picea abies & [38] \\
\hline 22 & 23.2 & 389.1236 & $\mathrm{C}_{20} \mathrm{H}_{22} \mathrm{O}_{8}$ & $\begin{array}{c}227.0745 ; 185.0652 \\
143.0537\end{array}$ & $\begin{array}{l}\text { Resveratrol } \\
\text { hexoside }\end{array}$ & Picea abies & [38] \\
\hline 23 & 23.5 & 303.0575 & $\mathrm{C}_{15} \mathrm{H}_{12} \mathrm{O}_{7}$ & $\begin{array}{c}285.0469 ; 259.0696 \\
125.0279\end{array}$ & Taxifolin & $\begin{array}{l}\text { Picea abies } \\
\text { Pinus nigra }\end{array}$ & {$[32,34]$} \\
\hline 24 & 23.8 & 419.1329 & $\mathrm{C}_{21} \mathrm{H}_{24} \mathrm{O}_{9}$ & 257.0856 & Isorhapontigenin hexoside & Picea abies & {$[38]$} \\
\hline 25 & 25.1 & 243.0619 & $\mathrm{C}_{14} \mathrm{H}_{12} \mathrm{O}_{4}$ & $\begin{array}{c}215.0696 ; 201.0594 \\
109.0280\end{array}$ & Piceatannol & Picea abies & [38] \\
\hline 26 & 26.1 & 447.1009 & $\mathrm{C}_{21} \mathrm{H}_{20} \mathrm{O}_{11}$ & $301.0323 ; 255.0569$ & $\begin{array}{l}\text { Quercetin } \\
\text { rhamnoside }\end{array}$ & Picea abies & {$[25,33]$} \\
\hline 27 & 26.4 & 809.2260 & $\mathrm{C}_{40} \mathrm{H}_{42} \mathrm{O}_{18}$ & $\begin{array}{c}647.1892 ; 405.1233 \\
243.715\end{array}$ & Piceaside A/B/G/H & Picea abies & [38] \\
\hline
\end{tabular}


Table 1. Cont.

\begin{tabular}{|c|c|c|c|c|c|c|c|}
\hline No. & $\begin{array}{c}\mathrm{T}_{\mathrm{R}} \\
{[\mathrm{min}]}\end{array}$ & $\begin{array}{c}{[\mathbf{M}-\mathbf{H}]^{-}} \\
\quad[\mathrm{m} / z]\end{array}$ & MF & $\begin{array}{l}\text { MS/MS Fragments } \\
\qquad[\mathrm{m} / \mathrm{z}]\end{array}$ & $\begin{array}{l}\text { Proposed } \\
\text { Identity }\end{array}$ & Sample & Ref. \\
\hline 28 & 26.9 & 837.2621 & $\mathrm{C}_{42} \mathrm{H}_{46} \mathrm{O}_{18}$ & $\begin{array}{c}675.2224 ; 513.1569 \\
243.0739\end{array}$ & Piceaside $\mathrm{O} / \mathrm{P}$ & Picea abies & [39] \\
\hline 29 & 28.9 & 823.2461 & $\mathrm{C}_{41} \mathrm{H}_{44} \mathrm{O}_{18}$ & $\begin{array}{l}\text { 661.2020; 499.1511; } \\
\text { 403.0937; 241.0567 }\end{array}$ & Piceaside E/F & Picea abies & [38] \\
\hline 30 & 29.8 & 647.1749 & $\mathrm{C}_{34} \mathrm{H}_{32} \mathrm{O}_{13}$ & $\begin{array}{c}585.2230 ; 485.1132 \\
451.1132\end{array}$ & Piceaside J/K & Picea abies & [38] \\
\hline 31 & 30.2 & 257.0827 & $\mathrm{C}_{15} \mathrm{H}_{14} \mathrm{O}_{4}$ & $241.0521 ; 224.0468$ & Isorhapontigenin & Picea abies & [38] \\
\hline 32 & 30.7 & 647.1778 & $\mathrm{C}_{34} \mathrm{H}_{32} \mathrm{O}_{13}$ & $\begin{array}{c}485.1267 ; 405.1142 \\
243.0645\end{array}$ & Piceaside I/J/K & Picea abies & [38] \\
\hline
\end{tabular}

MF: molecular formula; $\mathrm{T}_{\mathrm{R}}$ : retention time; ${ }^{*}$ confirmed with standard.

\subsection{Synthesis of AgNPs}

AgNPs were synthesized using a previously described method consisting, in brief, in stirring each aqueous bark extract with $\mathrm{AgNO}_{3}(1 \mathrm{mM})$ for $60 \mathrm{~min}$ at room temperature [40]. The synthesis of AgNPs was assessed spectrophotometrically, the spectrum of each reaction mixture being recorded at different intervals during 60 min stirring and post-stirring $(1,2,3$, 24 and $48 \mathrm{~h}$ ). The formation of AgNPs is indicated by a visible colour change of the reaction mixture caused by the reduction of $\mathrm{Ag}^{+}$to $\mathrm{Ag}^{0}$ and concomitant oxidation of the phenolic moieties into quinones. In addition, a Surface Plasmon Resonance (SPR) band occurs between 420 and $500 \mathrm{~nm}$ due to the collective oscillations of metal free electrons $[4,40,41]$. In our study, the colour of both reaction mixtures turned from light brown to dark reddish brown after a $60 \mathrm{~min}$ reaction time. The UV-Vis spectra of the colloidal solutions of AgNPs, recorded during stirring and post-stirring, are shown in Figure 2. The SPR bands at 462 and $423 \mathrm{~nm}$ confirmed the formation of AgNPs by Picea abies and Pinus nigra bark extracts, respectively. According to the literature, the lower $\lambda_{\max }$ value for Pinus nigra bark extract derived AgNPs (423 nm) indicates smaller size nanoparticles [42]. For both extracts, the intensity of SPR bands increased with time tending to stabilize after $24 \mathrm{~h}$, more apparently for Pinus nigra bark extract derived AgNPs. The latter sharpened over time with no change in position whereas Picea abies bark extract derived AgNPs showed broader SPR bands which slightly shifted from shorter to longer wavelengths over time. Shifting from shorter to longer wavelengths indicates an increase in AgNPs dimensions [42]. At each time interval, both Picea abies and Pinus nigra bark extract derived AgNPs showed single SPR bands. According to previous studies, single sharp SPR bands suggest that AgNPs have a spherical shape and do not aggregate in large clusters $[4,43,44]$. Overall, according to the UV-Vis spectroscopic data, 60 min stirring followed by $24 \mathrm{~h}$ at rest was established to be the optimal reaction time with respect to the accumulation of AgNPs but also their size and stability. In Picea abies and Pinus nigra bark extract derived AgNPs solutions, the concentration of AgNPs was calculated to be $6.67 \times 10^{-10}$ and $6.89 \times 10^{-10} \mathrm{~mol} / \mathrm{L}$, respectively. 

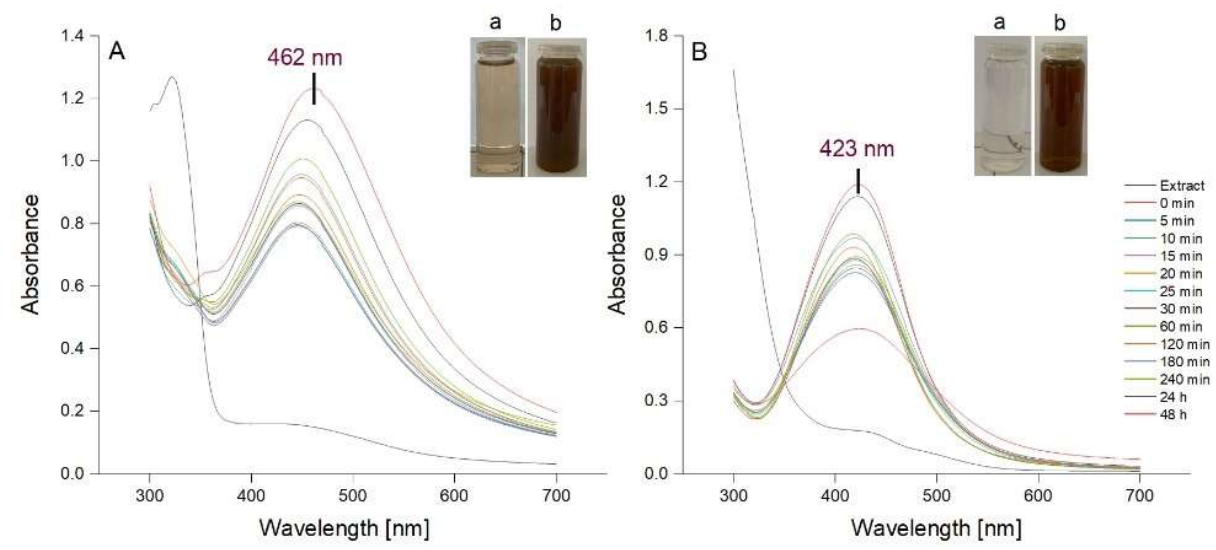

Figure 2. UV-Vis absorption spectra of AgNPs colloidal solutions synthesized using Picea abies (A) and Pinus nigra (B) aqueous bark extracts (a: extract $+1 \mathrm{mM} \mathrm{AgNO}_{3}$ at time 0 ; b: extract $+1 \mathrm{mM}$ $\mathrm{AgNO}_{3}$ at $\left.60 \mathrm{~min}\right)$.

\subsection{Attenuated Total Reflection Fourier Transform Infrared Spectroscopy}

Attenuated total reflection Fourier-transform infrared (ATR-FTIR) spectroscopy was performed to identify the compounds in bark extracts which are responsible for the reduction of $\mathrm{Ag}^{+}$to $\mathrm{Ag}^{0}$ and stabilization of AgNPs. The ATR-FTIR spectra of bark extracts and their derived AgNPs are illustrated in Figure 3. Picea abies and Pinus nigra bark extracts (Figure 3A,B) showed strong absorption bands at $3288 \mathrm{~cm}^{-1}$ and $3276 \mathrm{~cm}^{-1}$, respectively, corresponding to the stretching vibrations of $\mathrm{O}-\mathrm{H}$ groups $[45,46]$. These bands can be correlated with the presence of polyphenols, carbohydrates, and proteins in bark extracts. The bands at $2923 \mathrm{~cm}^{-1}$ and $2921 \mathrm{~cm}^{-1}$ (Picea abies and Pinus nigra bark extracts, respectively) denote the $\mathrm{C}-\mathrm{H}$ stretching vibration [47]. Bands belonging to the stretching vibrations of the aromatic rings and $=\mathrm{C}-\mathrm{O}-\mathrm{C}$ groups of flavonoids occur around $1600 \mathrm{~cm}^{-1}, 1500 \mathrm{~cm}^{-1}$, $1450 \mathrm{~cm}^{-1}$ and $1270 \mathrm{~cm}^{-1}$ in the spectra of both bark extracts [45]. The band at $1513 \mathrm{~cm}^{-1}$ (both extracts) could also be ascribed to the amide II region in proteins [48] whereas the bands at $1016 \mathrm{~cm}^{-1}$ (Picea abies bark extract) and $1025 \mathrm{~cm}^{-1}$ (Pinus nigra bark extract) might belong to the $\mathrm{C}-\mathrm{O}-\mathrm{C}$ stretching vibration in carbohydrates $[49,50]$. The bands at $765 \mathrm{~cm}^{-1}$ (Picea abies bark extract), $816 \mathrm{~cm}^{-1}$ and $775 \mathrm{~cm}^{-1}$ (Pinus nigra bark extract) denote the aromatic $\mathrm{C}-\mathrm{H}$ out of plane bending vibrations, the ones at $765 \mathrm{~cm}^{-1}$ and $775 \mathrm{~cm}^{-1}$ being characteristic for the $\mathrm{B}$ ring of flavonoids [51]. For both bark extracts, polyphenols were undoubtedly the major contributors in the green synthesis and stabilization of AgNPs. Apart from polyphenols, carbohydrates and proteins might also have played a role, acting as reducing and/or stabilizing agents [52]. The ATR-FTIR spectra of AgNPs (Figure 3A,B) illustrate the functional groups belonging to the capping/stabilizing molecules which are present on their surface. The typical IR bands in bark extracts are also observed in AgNPs spectra, but they are attenuated and/or shifted suggesting a synergy between polyphenols and other phytochemicals in bark extracts in the stabilization of AgNPs $[53,54]$. The intensity of the band at $3288 \mathrm{~cm}^{-1}$ almost disappeared in the ATR-FTIR spectra of Picea abies bark extract-derived AgNPs indicating that $\mathrm{O}-\mathrm{H}$ groups were almost entirely involved in the reduction of $\mathrm{Ag}^{+}$to $\mathrm{Ag}^{0}$. 

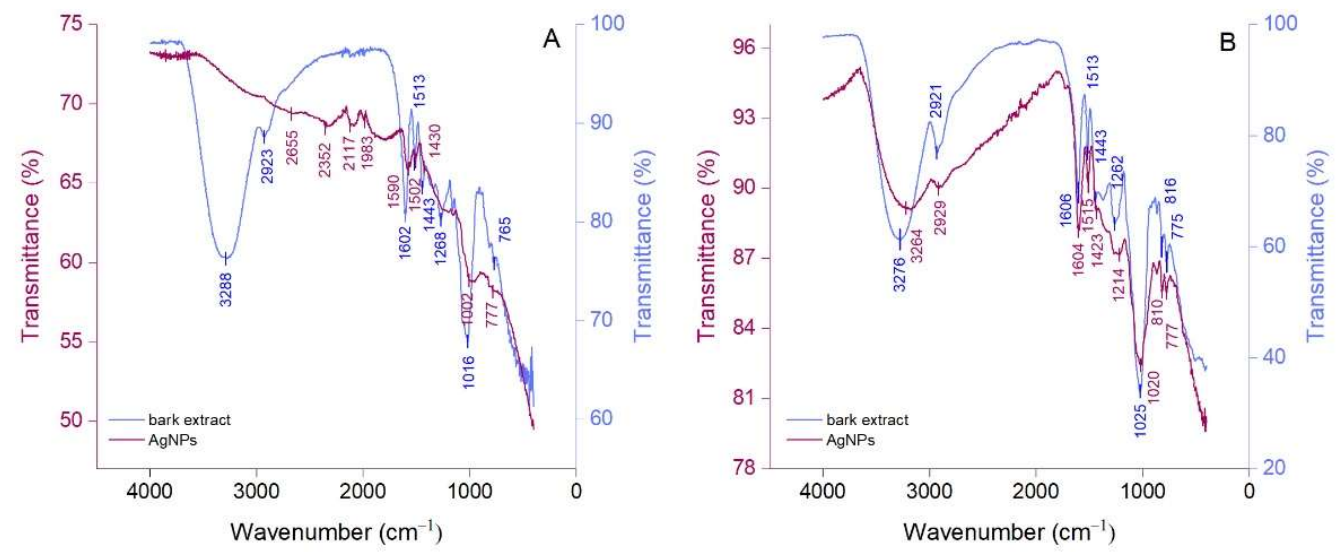

Figure 3. ATR-FTIR spectra of Picea abies (A) and Pinus nigra (B) bark extracts and their derived AgNPs.

\subsection{Raman Spectroscopy Analysis}

The functional groups on the surface of AgNPs were also investigated by Raman spectroscopy. Raman spectra of Picea abies and Pinus nigra bark extract derived AgNPs (colloidal solutions) are depicted in Figure 4A,B, respectively. Both spectra show intense Raman bands at similar wavenumbers. The bands at $1332 \mathrm{~cm}^{-1}$ and $1514 \mathrm{~cm}^{-1}$ (Figure $4 \mathrm{~A}$ ), $1331 \mathrm{~cm}^{-1}$ and $1524 \mathrm{~cm}^{-1}$ (Figure $4 \mathrm{~B}$ ) correspond to the symmetric and asymmetric $\mathrm{C}=\mathrm{O}$ stretching vibrations [53,55]. Bands at $799 \mathrm{~cm}^{-1}$ (Figure 4A) and $805 \mathrm{~cm}^{-1}$ (Figure 4B) could be ascribed to the stretching vibration of the glycosidic $\mathrm{C}-\mathrm{O}-\mathrm{C}$ linkage [55]. Amides are also presumed to be present due to the $\mathrm{N}-\mathrm{H}$ bending vibrations at $439 \mathrm{~cm}^{-1}$ (Figure $4 \mathrm{~A}$ ) and $422 \mathrm{~cm}^{-1}$ (Figure 4B) $[53,56]$. Other bands $\left(1641 \mathrm{~cm}^{-1}\right.$ in Figure $4 \mathrm{~A}$ and $1621 \mathrm{~cm}^{-1}$ in Figure $4 \mathrm{~B}$ ) are related to the $\mathrm{C}-\mathrm{C}$ stretching vibrations $[55,56]$. It is known that polyphenols bind to AgNPs surface through the $\mathrm{C}=\mathrm{O}$ moieties of quinones (formed by oxidation of phenolic hydroxyl groups) and/or carboxylate groups (in case of phenolic acids) [4,27]. Proteins and acidic carbohydrates also attach to AgNPs through carboxylate groups; in case of proteins, amino groups might also be involved [47,57]. According to Raman spectroscopy data, polyphenols and other phytochemicals (carbohydrates, proteins) are responsible for the stabilization of AgNPs.

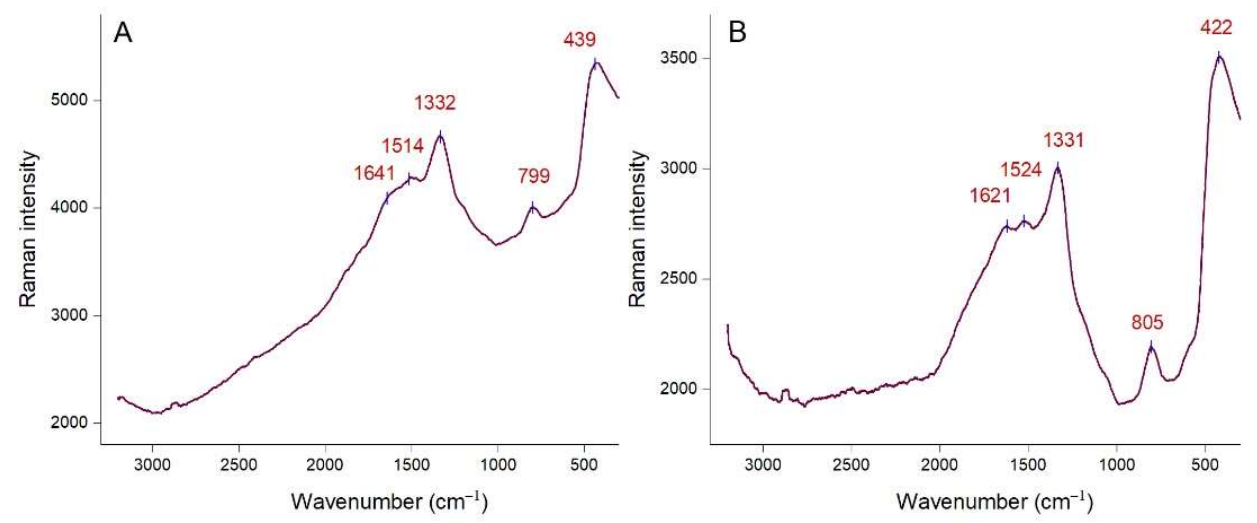

Figure 4. Raman spectra of Picea abies (A) and Pinus nigra (B) bark extract derived AgNPs.

\subsection{Dynamic Light Scattering Analysis}

The hydrodynamic diameter (Z-average), polydispersity index (PDI) and zeta potential values of Picea abies and Pinus nigra bark extract derived AgNPs were determined by dynamic light scattering (DLS) analysis (Figure 5). Z-average is the mean hydrodynamic diameter; PDI and zeta potential estimate the width of distribution and stability of AgNPs, respectively [58]. The hydrodynamic diameters of Picea abies and Pinus nigra bark extract 
derived AgNPs varied from 22.25 to $125.3 \mathrm{~nm}$ (Z-average $78.48 \mathrm{~nm}$ ) and 20.43 to $103.7 \mathrm{~nm}$ (Z-average $77.66 \mathrm{~nm}$ ), respectively. The values of PDI (0.334 and 0.224 for Picea abies and Pinus nigra bark extract derived AgNPs, respectively) indicate a narrow particle size distribution. As already mentioned, PDI estimates the homogeneity of size distribution in colloidal AgNPs solutions. PDI values higher than 0.7 denote a broad particle size distribution, lower values indicating better homogeneity [59]. The negative values of zeta potential (-10.8 and $-14.6 \mathrm{mV}$ for Picea abies and Pinus nigra bark extract derived AgNPs, respectively) indicate the stability of the synthesized nanoparticles [43,48]. It is well-known that the electrostatic repulsion between the negatively charged nanoparticles prevents their agglomeration, conferring high dispersity and good stability in time $[48,60]$.

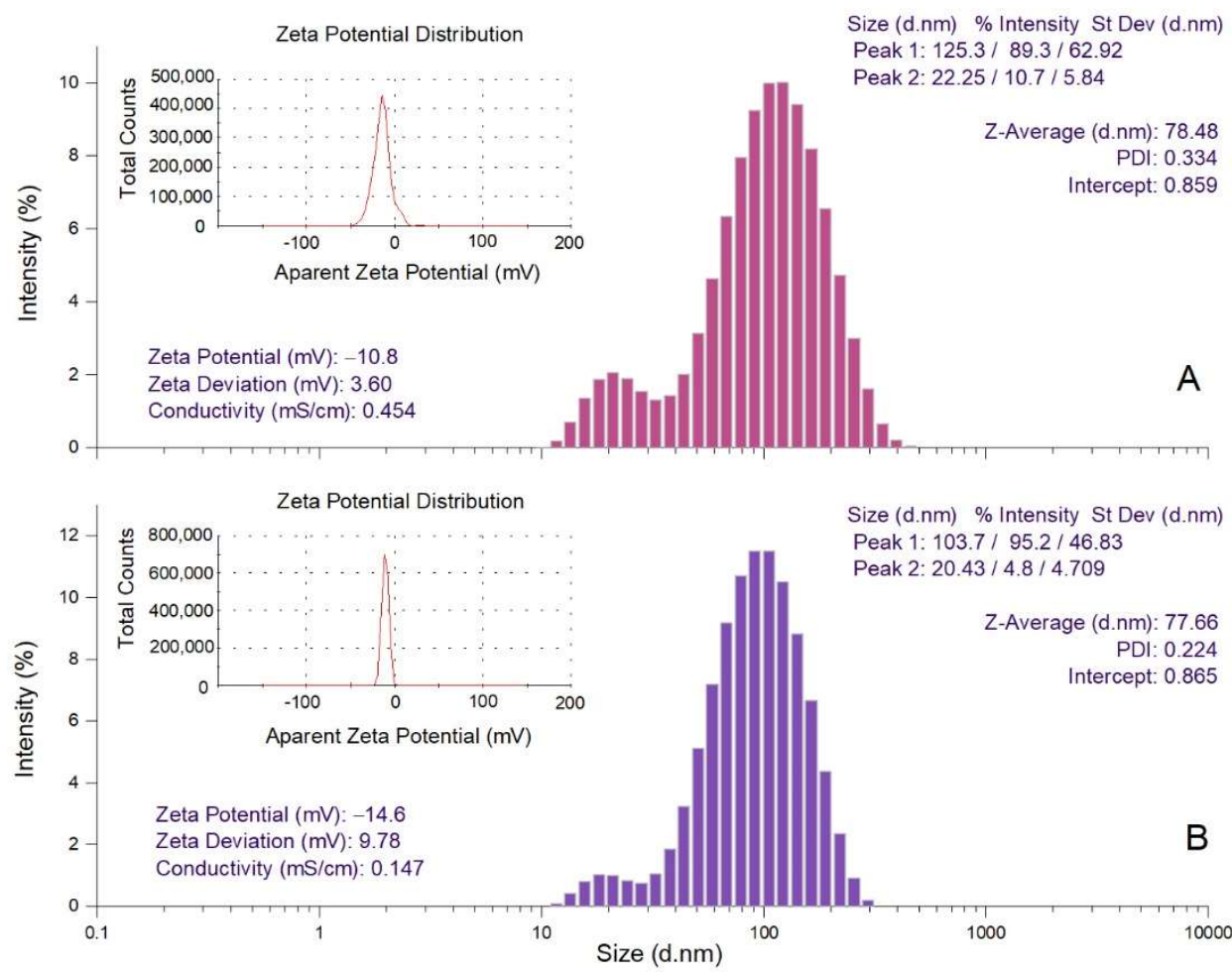

Figure 5. DLS analysis of Picea abies (A) and Pinus nigra (B) bark extract derived AgNPs (Z-averagehydrodynamic diameter; PDI-polydispersity index; d.nm-diameter in $\mathrm{nm}$ ).

\subsection{Scanning Electron Microscopy and Energy Dispersive X-ray Analysis}

Scanning electron microscopy (SEM) was used to observe the surface morphology of AgNPs whereas energy dispersive X-ray analysis (EDX) was conducted to identify and quantify the chemical elements found in AgNPs. The surface morphology of AgNPs visualized by SEM is illustrated in Figure 6. Both Picea abies and Pinus nigra bark extract-derived AgNPs showed irregular agglomerations (Figure 6B,D). As the transmission electron microscopy (TEM) analysis revealed that synthesized AgNPs were spherical in shape and well dispersed (Figure 7), it might be assumed that nanoparticle aggregation occurred during the low vacuum drying in SEM analysis. Both EDX spectra (Figure 6A,C) showed the presence of strong signal of $\mathrm{Ag}$ around $3 \mathrm{keV}$. Weaker signals for other elements $(\mathrm{C}, \mathrm{O}$, $\mathrm{N}, \mathrm{Cl}$ ) are also visible. According to the literature data, they belong to the compounds in plant extracts which bind to the surface of AgNPs and stabilize them acting as capping agents [44]. 

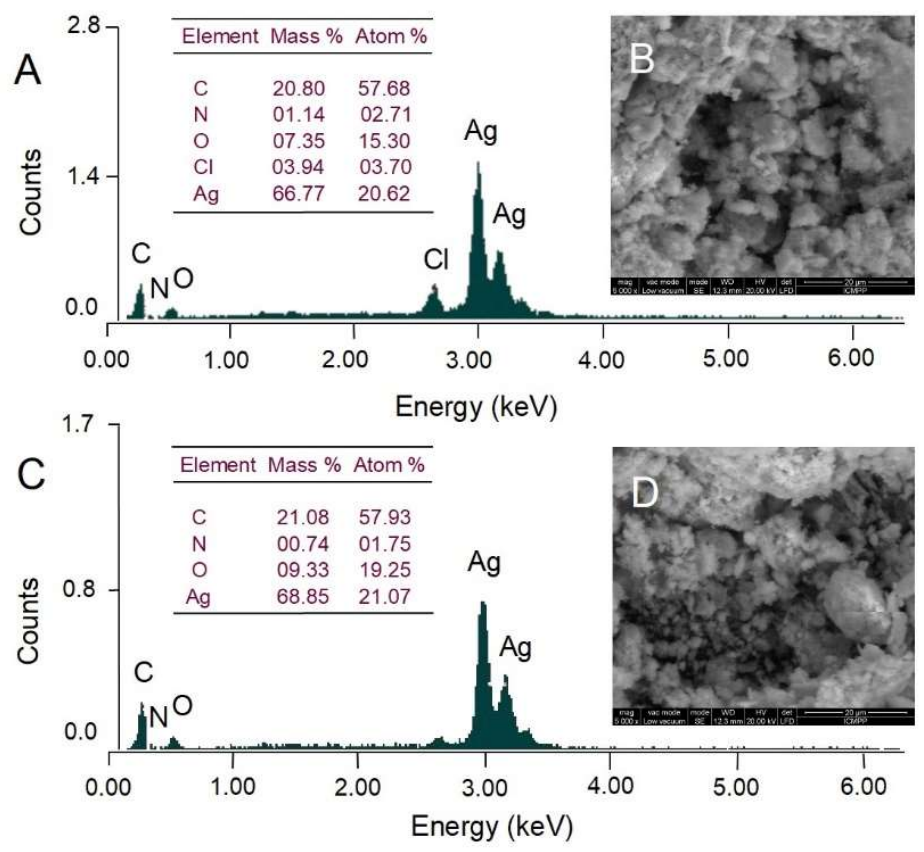

Figure 6. Elemental composition (EDX analysis) and scanning electron microscopy (SEM) micrographs of Picea abies (A,B) and Pinus nigra (C,D) bark extract derived AgNPs.
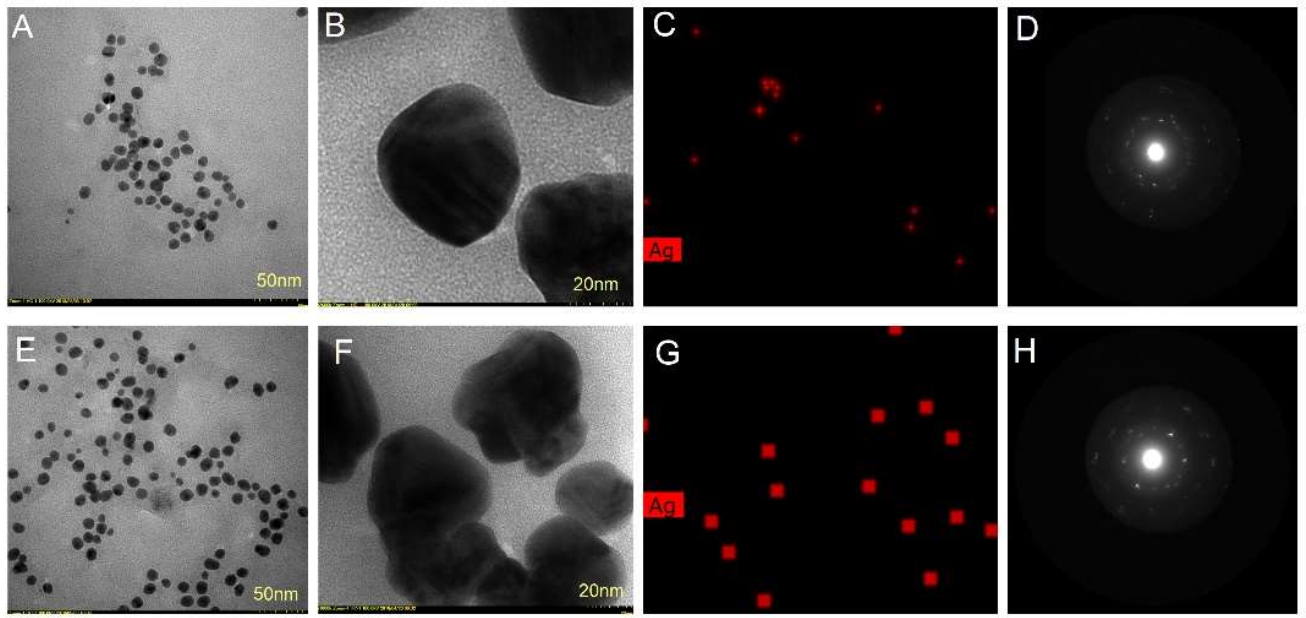

Figure 7. Picea abies bark extract derived AgNPs: TEM micrographs (A,B), TEM-EDX mapping (C) and SAED pattern (D); Pinus nigra bark extract derived AgNPs: TEM micrographs (E,F), TEM-EDX mapping $(\mathbf{G})$ and SAED pattern $(\mathbf{H})$.

\subsection{Transmission Electron Microscopy Analysis}

The size, shape and morphology of AgNPs were also investigated by TEM analysis. TEM images showed that AgNPs synthesized with both bark extracts had a roughly spherical shape (Figure 7A,B,E,F). Their sizes ranged from 25 to $75 \mathrm{~nm}$ and 15 to $55 \mathrm{~nm}$ for Picea abies and Pinus nigra bark extract derived AgNPs, respectively. The nanoparticle diameters measured by TEM were lower than the ones found by DLS. The differences are mainly due to the fact that DLS determines the hydrodynamic diameter, namely the diameter of the particle together with the molecules or ions attached to its surface in solution (hydrated state) whereas TEM measures the size of vacuum-dehydrated particles [47,58,61]. EDX mapping showed the elemental Ag distribution (the red dots) confirming the reduction of $\mathrm{Ag}^{+}$by Picea abies (Figure 7C) and Pinus nigra (Figure 7G) bark extracts. The selected area electron diffraction (SAED) patterns of Picea abies (Figure 7D) and Pinus nigra (Figure 7H) bark extract derived AgNPs showed strong crystalline reflections indicating the crystalline 
nature of AgNPs. In addition, the lattice fringes observed in the high-resolution TEM mode (Figure 7D,H) represent a direct proof of AgNPs crystallinity.

To the best of our knowledge, the use of conifer bark extracts in the green synthesis of AgNPs has hitherto been poorly investigated. The aqueous extract of Pinus eldarica bark generated AgNPs of spherical shape and sizes ranging from 10 to $40 \mathrm{~nm}$ [62]. A recent study has reported on the synthesis of AgNPs derived from Picea abies bark using different experimental protocols than the ones employed in our study. Thereby, the aqueous bark extract was prepared by ultrasound-assisted extraction $\left(70^{\circ} \mathrm{C}, 30 \mathrm{~min}\right)$; AgNPs were obtained by ultrasound-assisted synthesis at $60^{\circ} \mathrm{C}$ for $3 \mathrm{~h}$ using different salts $\left(\mathrm{AgNO}_{3}\right.$ or silver acetate, $10 \mathrm{~mL}$ of aqueous bark extract mixed with $90 \mathrm{~mL}$ of $1 \mathrm{mM} \mathrm{AgNO}_{3} /$ silver acetate) and different $\mathrm{pH}$ values (4 or 9). The resulted AgNPs were spherical and polygonal with average sizes ranging from 44 to $165 \mathrm{~nm}$; AgNPs having a spherical shape and less than $100 \mathrm{~nm}$ average size were obtained at $\mathrm{pH}=9$ [54]. Another method (constant stirring of Picea abies aqueous bark extract and $1 \mathrm{mM} \mathrm{AgNO}, 1: 10,70{ }^{\circ} \mathrm{C}, \mathrm{pH}=9,3 \mathrm{~h}$ ) generated AgNPs with an average diameter of $226 \mathrm{~nm}$ [63]. According to the literature data, AgNPs with size below $100 \mathrm{~nm}$ are highly active against Gram-positive and Gram-negative bacteria, viruses and other pathogenic microorganisms [64]. In the present study, the protocol used for AgNPs synthesis was simple and provided spherical AgNPs with average sizes below $100 \mathrm{~nm}$, as revealed by DLS and TEM analyses.

\subsection{Antimicrobial Activity}

The antimicrobial effects of AgNPs and bark extracts used for their synthesis were assessed by the disk diffusion method against Gram-positive (methicillin-susceptible Staphylococcus aureus (MSSA), methicillin-resistant Staphylococcus aureus (MRSA), Staphylococcus epidermidis, Streptococcus pyogenes) and Gram-negative (Escherichia coli, Pseudomonas aeruginosa) bacteria and fungi (Candida albicans). The results are depicted in Table 2.

Table 2. Diameters of inhibition zones $(\mathrm{mm})$ developed by AgNPs and bark extracts used for their synthesis against pathogenic bacteria and fungi.

\begin{tabular}{|c|c|c|c|c|c|c|}
\hline Microorganism & Nystatin & Gentamicin & $\begin{array}{l}\text { P. abies- } \\
\text { AgNPs }\end{array}$ & $\begin{array}{l}\text { P. abies } \\
\text { Extract }\end{array}$ & $\begin{array}{l}\text { P. nigra- } \\
\text { AgNPs }\end{array}$ & $\begin{array}{l}\text { P. nigra } \\
\text { Extract }\end{array}$ \\
\hline $\begin{array}{c}\text { S. aureus } \\
\text { ATCC } 25293\end{array}$ & ND & $23.00 \pm 0.58^{n c}$ & $14.67 \pm 0.58^{\mathrm{nc}, \mathrm{a}}$ & $\underset{\mathrm{nc}, \mathrm{a}, \mathrm{b}}{13.00 \pm 1.73}$ & $\begin{array}{c}16.00 \pm 2.64 \\
n c, a, b, a\end{array}$ & NA \\
\hline $\begin{array}{c}\text { S. aureus } \\
\text { ATCC } 33591 \\
\text { (MRSA) }\end{array}$ & ND & $15.67 \pm 0.58^{\mathrm{nc}}$ & $15.67 \pm 1.15^{\mathrm{nc}, \mathrm{c}}$ & $\underset{\mathrm{nc}, \mathrm{a}, \mathrm{a}}{10.67 \pm 0.58}$ & $\begin{array}{c}14.67 \pm 0.58 \\
\text { nc,b,b,a }\end{array}$ & $\begin{array}{c}10.67 \pm 1.15 \\
\text { nc,a,a, } \mathrm{c}, \mathrm{b}\end{array}$ \\
\hline $\begin{array}{c}\text { S. aureus } \\
\text { ATCC } 43300 \\
\text { (MRSA) }\end{array}$ & ND & $7.67 \pm 0.58^{\mathrm{nc}}$ & $15.33 \pm 0.58^{\mathrm{nc}, \mathrm{a}}$ & $7.67 \pm 0.58^{\mathrm{nc}, \mathrm{c}, \mathrm{a}}$ & $15 \pm 1.0^{\mathrm{nc}, \mathrm{a}, \mathrm{c}, \mathrm{a}}$ & NA \\
\hline $\begin{array}{l}\text { S. epidermidis } \\
\text { ATCC } 12228\end{array}$ & ND & $29.67 \pm 0.58^{n c}$ & $19.00 \pm 1.73^{\mathrm{nc}, \mathrm{a}}$ & $\underset{\mathrm{nc}, \mathrm{a}, \mathrm{a}}{14.67 \pm 1.15}$ & $16 \pm 1.0^{\mathrm{nc}, \mathrm{a}, \mathrm{a}, \mathrm{b}}$ & $12 \pm 0.0^{\mathrm{nc}, \mathrm{a}, \mathrm{a}, \mathrm{b}, \mathrm{a}}$ \\
\hline $\begin{array}{c}\text { S. pyogenes } \\
\text { ATCC } 19615\end{array}$ & ND & $18.33 \pm 1.15^{\mathrm{nc}}$ & $12.67 \pm 0.58^{\mathrm{nc}, \mathrm{b}}$ & NA & $13 \pm 1.0^{\mathrm{nc}, \mathrm{a}, \mathrm{c}, \mathrm{nc}}$ & NA \\
\hline $\begin{array}{c}\text { E. coli } \\
\text { ATCC } 25922\end{array}$ & ND & $20.67 \pm 0.58^{n c}$ & $14 \pm 1^{\mathrm{nc}, \mathrm{a}}$ & NA & $\begin{array}{l}16.33 \pm 2.08 \\
\text { nc,a,b,nc }\end{array}$ & NA \\
\hline $\begin{array}{l}\text { P. aeruginosa } \\
\text { ATCC } 9027\end{array}$ & ND & $23.33 \pm 0.58^{\mathrm{nc}}$ & $13 \pm 1^{\mathrm{nc}, \mathrm{a}}$ & NA & $\begin{array}{c}13.67 \pm 0.58 \\
\mathrm{nc}, \mathrm{a}, \mathrm{c}, \mathrm{nc}\end{array}$ & NA \\
\hline $\begin{array}{c}\text { C. albicans } \\
\text { ATCC } 90028\end{array}$ & $21.33 \pm 0.58$ & $\mathrm{ND}^{\mathrm{nc}}$ & $16.25 \pm 1.73^{\mathrm{a}, \mathrm{nc}}$ & $7.91 \pm 1.15^{\mathrm{a}, \mathrm{nc}, \mathrm{a}}$ & $\underset{\mathrm{a}, \mathrm{nc}, \mathrm{b}, \mathrm{a}}{14.67 \pm 1.52}$ & $\begin{array}{c}9.33 \pm 1.15 \\
\mathrm{a}, \mathrm{nc}, \mathrm{a}, \mathrm{b}, \mathrm{a}\end{array}$ \\
\hline
\end{tabular}

ND: not determined; NA: no activity; ${ }^{\text {nc }}$ : not computed; ${ }^{\mathrm{a}}: p<0.001{ }^{\mathrm{b}}{ }^{\mathrm{b}}: p<0.05{ }^{\mathrm{c}}$ : no significance.

Picea abies and Pinus nigra bark extract derived AgNPs showed growth inhibition zones comparable with or larger than those developed by gentamicin $(10 \mu \mathrm{g})$ against $S$. 
aureus ATCC 33591 and S. aureus ATCC 43300, respectively, both MRSA strains. AgNPs also inhibited the growth of $S$. pyogenes, E. coli and P. aeruginosa whereas bark extracts showed no activity against these bacterial strains. In addition, AgNPs developed larger inhibition zones against $C$. albicans in comparison with bark extracts. It is noteworthy to mention the efficacy of AgNPs against Gram-negative bacteria (E. coli, P. aeruginosa). The latter have a lipopolysaccharide outer layer (lipids covalently bound to polysaccharides) which considerably reduces the penetration of hydrophobic antibiotics inside bacteria; Gram-negative bacteria thus have less susceptibility to antibiotics than Gram-positive ones $[65,66]$. Overall, according to the inhibition zone diameters, Picea abies and Pinus nigra bark extract derived AgNPs exhibited stronger antimicrobial activity against all tested microbial strains than the corresponding bark extracts; both AgNPs and bark extracts were tested at $25 \mu \mathrm{L}$. The mechanisms involved in the antimicrobial activity of AgNPs have already been described. In brief, AgNPs bind to the bacterial/fungal cell surface through electrostatic forces and disrupt its integrity penetrating inside the cell. Then, AgNPs slowly release $\mathrm{Ag}^{+}$which triggers the formation of reactive oxygen species. Oxidative stress negatively affects DNA replication and mitochondrial pathways with a reduction in ATP levels and induction of mitochondria-dependent apoptosis. Moreover, $\mathrm{Ag}^{+}$has strong affinity towards the thiol groups of proteins and enzymes, the interaction resulting in the disruption of metabolic reactions and cell death $[6,40,66]$. Various phytochemicals present on the surface of AgNPs (capping/stabilizing agents) might improve the adhesion of AgNPs to the microbial cells and their antimicrobial efficacy. For example, polyphenols are well-known antimicrobial agents, mainly due to their interaction with various proteins (enzymes, adhesins, cell envelope transport proteins), thus altering the microbial membrane and metabolic pathways [67].

Some of the antimicrobial activity investigated in this study is similar to that reported in previous studies conducted by Tanase et al., where AgNPs prepared from Picea abies bark showed good activity against pathogenic bacteria (MSSA, MRSA, E. coli, Klebsiella pneumoniae, P. aeruginosa) [54,63]. However, a comparison with our results is not feasible due to different assays used to evaluate the antibacterial activity (disk diffusion assay in our study, microdilution method in the previous studies).

\subsection{Cytogenotoxic Activity}

Due to their small size, AgNPs easily penetrate cellular and subcellular structures releasing $\mathrm{Ag}^{+}$responsible for deleterious effects such as increase in oxidative stress, DNA and RNA denaturation, blockage of electron transport chain and ATP formation. AgNPs showed toxicity against different cells and organisms, their toxicity being strongly dependent on size (particles less than $20 \mathrm{~nm}$ are highly toxic) and also on the shape, stability, and surface chemistry $[1,68]$. In the present study, the potential cytotoxic (antimitotic) and genotoxic effects of AgNPs and bark extracts used for their synthesis were evaluated using Allium cepa assay. The latter is a simple, reliable, and widely used test for assessing the cytogenotoxicity of a product [69]. The effects of AgNPs and bark extracts on cell division and chromosome behaviour in Allium cepa cells are summarized in Figures 8 and 9 and Table 3. Picea abies and Pinus nigra bark extracts and their derived AgNPs significantly decreased the number of dividing cells and consequently the mitotic index. The cytotoxic effects of AgNPs were more pronounced than those produced by the bark extracts. The mitotic index values of Allium cepa cells exposed to Picea abies and Pinus nigra bark extract derived AgNPs (1.27 $\pm 0.16 \%$ and $1.67 \pm 0.09 \%$, respectively) were almost half of those corresponding to the bark extracts $(2.80 \pm 0.17 \%$ and $2.97 \pm 0.14 \%$, respectively) and several-fold (6.18- and 4.7-fold, respectively) lower than the control (7.86 $\pm 0.23 \%)$. The percentages of cells in different mitotic phases were also calculated. The results clearly showed that AgNPs induced significant accumulation of cells in prophase $(85.17 \pm 0.77 \%$ and $84.32 \pm 2.60 \%$ for Picea abies and Pinus nigra bark extract derived AgNPs, respectively) in comparison with the bark extracts $(75.31 \pm 2.32 \%$ and $67.40 \pm 0.64 \%$ for Picea abies and Pinus nigra bark extracts, respectively) and control (53.80 $\pm 2.90 \%)$. AgNPs reduced 
the proportion of cells in metaphase, anaphase, and telophase in comparison with the control (Figure 8). The accumulation of cells in prophase induced by AgNPs and bark extracts can be ascribed to the inhibition of spindle fibers formation/function or G2 phase extension [22].
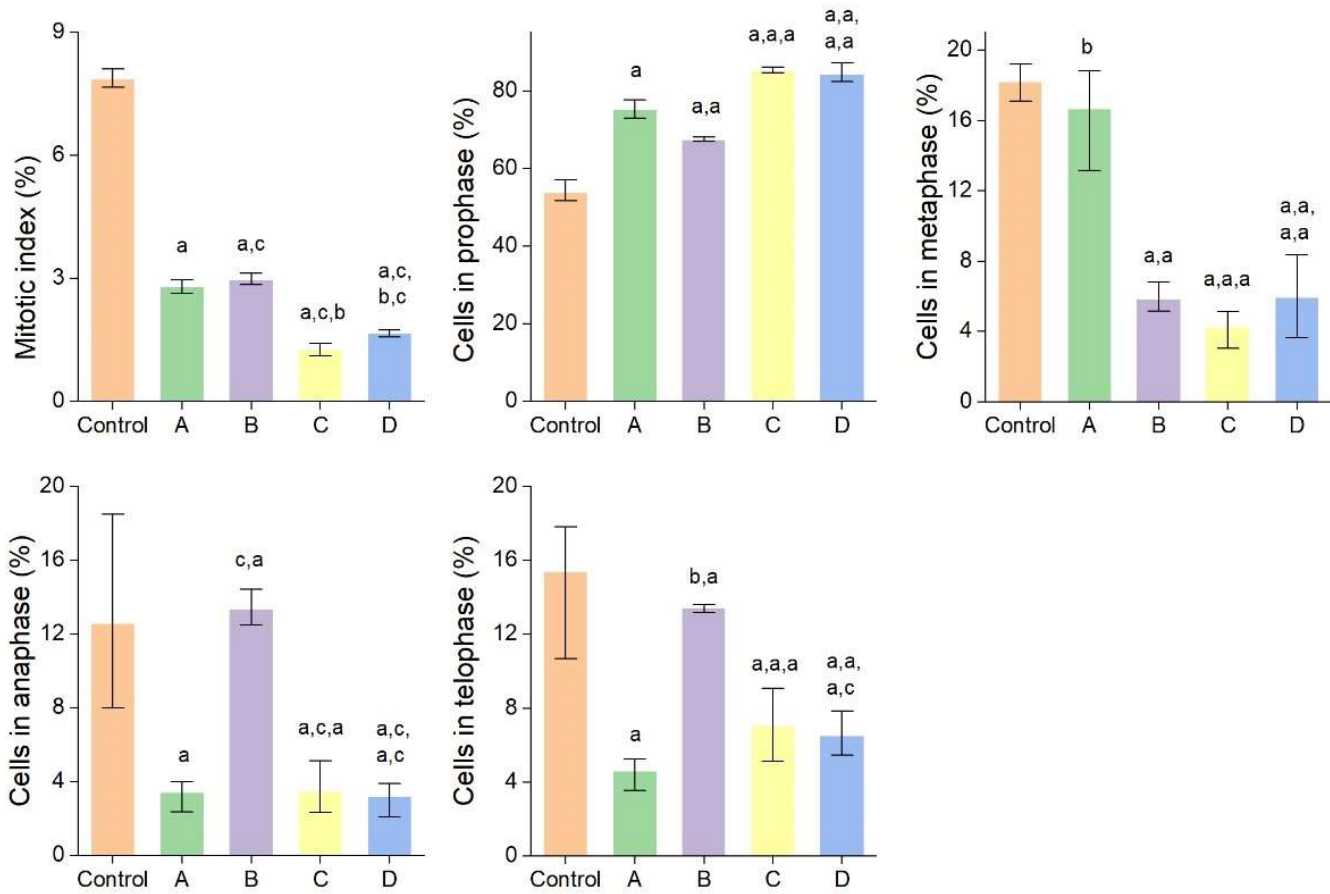

Figure 8. Mitotic index values and percentages of cells in mitosis stages in Allium cepa root meristems exposed to Picea abies bark extract (A), Pinus nigra bark extract (B), Picea abies bark extract derived AgNPs (C) and Pinus nigra bark extract derived AgNPs (D); ${ }^{a}: p<0.001 ;{ }^{b}: p<0.05$; ${ }^{\text {c }}$ no significance.

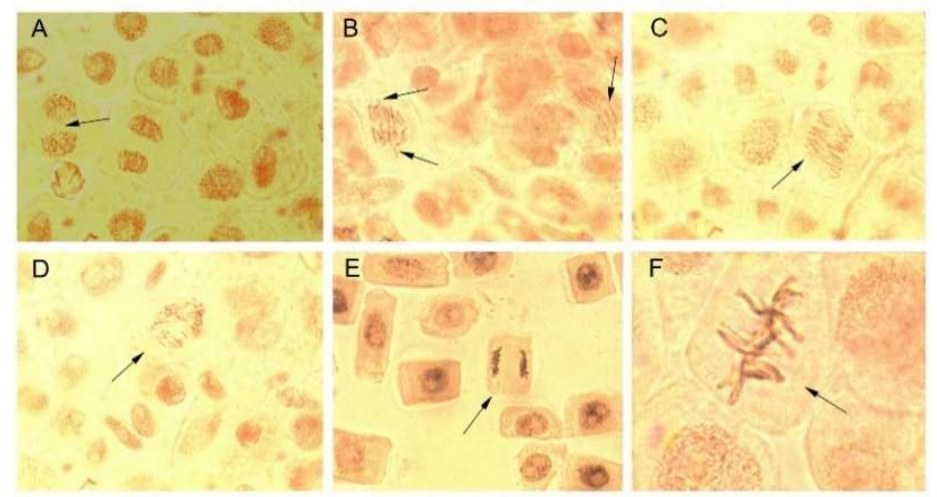

Figure 9. Chromosomal aberrations (A-C) and normal stages of mitotic division (D-F) in Allium cepa root meristems exposed to Picea abies and Pinus nigra bark extracts and their derived AgNPs. (A) telophase with two interrupted bridges (exposure to Picea abies bark extract); (B) incipient anaphase-telophases with vagrant chromosomes and multiple bridges (exposure to Picea abies bark extract derived AgNPs); (C) incipient anaphase-telophases with multiple bridges (exposure to Pinus nigra bark extract derived AgNPs); (D) normal pro-metaphase (control); (E) normal anaphase (control); (F) normal metaphase (control). 
Table 3. Impact of Picea abies and Pinus nigra bark extracts and their derived AgNPs on chromosomal aberrations in Allium cepa root meristems.

\begin{tabular}{cccc}
\hline Sample & Vagrants (\%) & $\begin{array}{c}\text { Multiple } \\
\text { Bridges (\%) }\end{array}$ & $\begin{array}{c}\text { Interrupted Bridges } \\
\text { (\%) }\end{array}$ \\
\hline $\begin{array}{c}\text { Control } \\
\text { Picea abies bark extract }\end{array}$ & $0.06 \pm 0.04$ & - & - \\
$\begin{array}{c}\text { Pinus nigra bark extract } \\
\text { Picea abies bark extract } \\
\text { derived AgNPs }\end{array}$ & $0.45 \pm 0.13^{\mathrm{a}}$ & - & $0.27 \pm 0.15$ \\
$\begin{array}{c}\text { Pinus nigra bark extract } \\
\text { derived AgNPs }\end{array}$ & $0.05 \pm 0.13^{\mathrm{a}, \mathrm{a}, \mathrm{a}}$ & $0.26 \pm 0.08 \pm 0.06^{\mathrm{a}}$ & - \\
\hline${ }^{\mathrm{a}: p<0.001 .}$ & & $0.55 \pm 0.07^{\mathrm{a}, \mathrm{a}, \mathrm{a}, \mathrm{a}}$ & - \\
\hline
\end{tabular}

Plant derived AgNPs were reported to cause different types of chromosomal aberrations in Allium cepa cells such as chromosomal stickiness in metaphase and anaphase, unoriented or clumping chromosomes in disturbed metaphase, bridges, vagrant and lagging chromosomes in anaphase-telophase, chromosome fragmentation, in addition to micronucleus at interphase and C-mitosis [22,69-71]. In our study, Picea abies and Pinus nigra bark extract derived AgNPs were found to induce anaphase-telophase chromosomal aberrations such as vagrant chromosomes (in $1.05 \pm 0.13 \%$ and $0.80 \pm 0.25 \%$ of the total dividing cells, respectively) and multiple bridges (in $0.50 \pm 0.06 \%$ and $0.55 \pm 0.07 \%$ of the total dividing cells, respectively) (Table 3, Figure 9). Vagrants are chromosomes moving ahead of their associated chromosomal groups toward cell poles. Thus, the chromosomes in daughter cells are unequally separated resulting in polyploidy and aneuploidy. Chromosomal bridges usually result from the non-disjunction of sticky chromosomes or dysfunctions in separation (breakage followed by unification) during anaphase leading to change or loss of genetic material [72,73].

Overall, Picea abies and Pinus nigra bark extract derived AgNPs depressed mitosis arresting cell division at prophase stage and induced vagrant chromosomes and multiple bridges to a greater degree than the corresponding bark extracts. In previous studies, the cytogenotoxic potential of plant derived AgNPs was assessed using different versions of Allium cepa assay. AgNPs derived from Melissa officinalis (lemon balm) ethanolic extracts (10\% and $20 \%$ ) attenuated the mitodepressive effects of the extracts used for their synthesis as revealed by a several-fold enhancement in the mitotic index values but caused an increase in the number of vagrants (2.8- and 1.5-fold, respectively) in comparison with the corresponding extracts. AgNPs synthesized with $10 \%$ M. officinalis ethanolic extract increased the number of micronuclei (2.5-fold), too [22]. When comparing with the control, AgNPs derived from cocoa pod husk and cocoa bean extracts significantly reduced the mitotic index (1.8-10.7-fold) with prophase cell accumulation $(2.84-10.55 \%$ increase in prophase cells) and induced C-mitosis, chromosomal bridges, sticky and vagrant chromosomes $(0.06-0.48 \%)$ [71]. Cell laggards, disturbed metaphases with clumping chromosomes and disturbed telophases were reported for other plant derived AgNPs [69]. It can be concluded that Picea abies and Pinus nigra bark extract derived AgNPs showed antimitotic potential which could be exploited for the development of formulations with antitumor activity. Similar to other AgNPs derived from plant extracts, AgNPs obtained in the present study induced chromosomal aberrations but they occurred at low frequencies $(\leq 1.05 \%$ of the total dividing cells).

\section{Materials and Methods}

\subsection{Chemicals and Reagents}

Folin-Ciocalteu's phenol reagent, gallic acid, sodium carbonate, silver nitrate $\left(\mathrm{AgNO}_{3}\right)$, carmine powder, hydrochloric acid 37\%, 1-butanol, catechin, epicatechin, formic acid and acetonitrile (LC grade), water (LC grade) were purchased from Sigma-Aldrich (Steinheim, Germany). Ammonium iron (III) sulphate dodecahydrate was purchased from Riedel- 
de-Haën (Seelze, Germany). Absolute ethanol and glacial acetic acid were supplied by Chimreactiv (Bucharest, Romania). Mueller-Hinton agar, gentamicin (10 $\mu \mathrm{g} /$ disk) and nystatin (100 units/disk) came from Oxoid (Basingstoke, UK). Potato dextrose agar came from Bio-Rad (Hercules, CA, USA). Ultrapure water was obtained from SG Water Ultra Clear TWF water purification system (Barsbüttel, Germany).

\subsection{Microorganisms}

Staphylococcus aureus ATCC 25293, ATCC 33591 and ATCC 43300, Staphylococcus epidermidis ATCC 12228, Streptococcus pyogenes ATCC 19615, Escherichia coli ATCC 25922, Pseudomonas aeruginosa ATCC 9027 and Candida albicans ATCC 90028 were purchased from the American Type Culture Collection (ATCC, Manassas, VA, USA).

\subsection{Plant Material and Extraction}

Picea abies and Pinus nigra bark fragments were sampled from a natural site located in Suceava county, Northeast Romania $\left(47^{\circ} 33^{\prime} 45^{\prime \prime} \mathrm{N}, 25^{\circ} 39^{\prime} 36^{\prime \prime}\right.$ E, elevation $\left.734 \mathrm{~m}\right)$ in March 2018. For each species, five full-grown trees (35-40 years old, $18-25 \mathrm{~cm}$ circumference at breast height) were randomly selected for collection. The plant material was identified and authenticated by Dr. Constantin Nechita (Forest Research and Management Institute, Campulung Moldovenesc, Suceava, Romania). Voucher samples (PA1503/2018, PN1603/2018) are deposited in the Department of Pharmacognosy, Faculty of Pharmacy, Grigore T. Popa University of Medicine and Pharmacy, Iasi, Romania.

Bark fragments were thoroughly rinsed with distilled and ultrapure water, chopped, dried at room temperature, under ventilation and low luminosity and ground to obtain a homogenous fine powder. Bark powders were extracted as previously described with minor changes [40]. In brief, $10 \mathrm{~g}$ of bark powder of Picea abies and Pinus nigra were mixed with $100 \mathrm{~mL}$ of ultrapure water at $60^{\circ} \mathrm{C}$ and stirred by magnetic stirrer $(400 \mathrm{rpm})$ for $3 \mathrm{~h}$ at room temperature. The extracts were filtered (Whatman no. 1 filter paper), adjusted to a volume of $100 \mathrm{~mL}$ with ultrapure water and stored at $-20^{\circ} \mathrm{C}$ until further use.

\subsection{Total Phenolic Content}

The total phenolic content of Picea abies and Pinus nigra bark extracts was determined using the Folin-Ciocalteu method as previously described [67]. The total phenolic content was expressed as $\mathrm{mg}$ gallic acid $/ \mathrm{mL}$ extract. The assay was performed in triplicate and the results were expressed as mean \pm standard deviation.

\subsection{Total Proanthocyanidin Content}

The total proanthocyanidin content was estimated by the butanol-hydrochloric acid assay as previously reported and expressed as cyanidin equivalents (mg cyanidin $/ \mathrm{mL}$ extract) using the molar extinction coefficient of cyanidin $\left(\varepsilon=17,360 \mathrm{~L} \cdot \mathrm{mol}^{-1} \cdot \mathrm{cm}^{-1}\right)[67,74]$. The assay was done in triplicate and the results were expressed as mean \pm standard deviation.

\subsection{HPLC-DAD-ESI-Q-TOF-MS/MS Analysis}

The phenolic profile in both bark extracts was analysed by HPLC-DAD-ESI-Q-TOFMS/MS. The analysis was performed on an Agilent 1200 HPLC system (Agilent Technologies, Santa Clara, CA, USA) equipped with auto-sampler (G1329B), degasser (G1379B), binary pump (G1312C), thermostat (G1316A), DAD detector (G1315D), Agilent ESI-Q-TOF mass spectrometer (G6530B), nitrogen generator (Parker Hannifin Corp., Cleveland, OA, USA) and compressed air generator (Jun-Air Oxymed, Łódź, Poland). A Phenomenex Gemini C18 $(100 \times 2 \mathrm{~mm}, 3 \mu \mathrm{m})$ column was used. The mobile phase consisted of $0.1 \%$ formic acid in water (A) and $0.1 \%$ formic acid in acetonitrile (B). The elution gradient, injection volume, flow rate, column temperature and ESI-Q-TOF-MS parameters were those reported by Luca et al. [31], except that the mass range varied from 100 to $1700 \mathrm{~m} / \mathrm{z}$. 
Data were processed with a MassHunter Qualitative Analysis Navigator B.08.00 software (Agilent).

\subsection{Green Synthesis of Colloidal Silver Nanoparticles}

For the green synthesis of AgNPs, Picea abies and Pinus nigra aqueous bark extracts ( $1 \mathrm{~mL}$ of each) were added to $100 \mathrm{~mL}$ of $1 \mathrm{mM} \mathrm{AgNO}$. After stirring for $60 \mathrm{~min}$ at room temperature, a stable reddish-brown colour appeared indicating the formation of AgNPs [40].

\subsection{UV-Vis Spectroscopy}

The formation of AgNPs was monitored by recording the UV-Vis spectrum of each reaction mixture in the wavelength range of 300-700 $\mathrm{nm}[47,58]$ on a Specord 210 Plus spectrophotometer (Analytik Jena, Jena, Thuringia, Germany). Samples were collected at different times $(0,5,10,15,20,25,30$ and $60 \mathrm{~min})$ after the start of stirring but also at 2, 3, 4,24 and $48 \mathrm{~h}$ after the end of stirring. At the aforementioned times, $1 \mathrm{~mL}$ of the reaction mixture was sampled and further diluted with $2 \mathrm{~mL}$ of ultrapure water in quartz cuvettes followed by recording the UV-Vis spectrum.

\subsection{Determination of Concentration of Silver Nanoparticles}

The concentration of AgNPs in colloidal solution was determined according to previous reports. In brief, the average number of atoms per nanoparticle $(N)$ was first calculated as follows:

$$
N=\frac{\pi \rho D^{3} N_{A}}{6 M}
$$

where $\pi=3.14, \rho=10.5 \mathrm{~g} / \mathrm{cm}^{3}$ (density of face centered, cubic Ag), $D=$ average diameter of nanoparticles (in cm), $M=107.868 \mathrm{~g}$ (atomic mass of Ag) and $N_{A}=6.023 \times 10^{23} \mathrm{~mol}^{-1}$ (Avogadro's number). Assuming that $\mathrm{Ag}^{+}$completely converted to AgNPs, the molar concentration of the nanoparticle solution $(\mathrm{C})$ was determined:

$$
C=\frac{N_{T}}{N V N_{A}}
$$

where $N_{T}=$ total amount of $\mathrm{Ag}$ atoms added as $\mathrm{AgNO}_{3}(1.0 \mathrm{mM}=0.001 \mathrm{M}), N=$ average number of atoms per nanoparticle, $V=$ reaction volume $(0.101 \mathrm{~L})$ and $N_{A}=6.023 \times$ $10^{23} \mathrm{~mol}^{-1}$ (Avogadro's number) $[75,76]$.

\subsection{ATR-FTIR Spectroscopy}

ATR-FTIR spectra of AgNPs and bark extracts were obtained on a Bruker Alpha-P ATR FTIR spectrometer with diamond crystal (Bruker, Ettlingen, Germany). Prior to analysis, the colloidal AgNPs solutions were centrifuged at $7000 \mathrm{rpm}$ for $20 \mathrm{~min}$ (Rotina $380 \mathrm{R}$ centrifuge, Hettich, Tuttlingen, Germany). The pellets were resuspended in ultrapure water and subjected again to centrifugation (7000 rpm, $20 \mathrm{~min}$ ) to eliminate unreacted $\mathrm{AgNO}_{3}$ and other free compounds that were not involved in the stabilization of AgNPs. The pellets were further freeze dried (Unicryo TFD 5505 freeze dryer, UniEquip GmbH, Munich, Germany). Bark extracts (30 mL of each) were concentrated under reduced pressure at $40{ }^{\circ} \mathrm{C}$ (Büchi R-210 rotary evaporator system, Büchi Labortechnik AG, Flawil, Switzerland) and freeze-dried. ATR-FTIR measurements were performed with a resolution of $4 \mathrm{~cm}^{-1}$ in the spectral region $4000-400 \mathrm{~cm}^{-1}$. Data were processed using Bruker OPUS spectroscopy software ver. 7 ed. 2011.

\subsection{Raman Spectroscopy}

Raman spectra of colloidal AgNPs solutions were recorded using an inVia confocal Raman microscope (Renishaw, Wotton-under-Edge UK) equipped with a high-power nearinfrared diode laser at $785 \mathrm{~nm}(300 \mathrm{~mW})$ and a Charge Coupled Device (CCD) detector coupled to a Leica DM2500 M microscope. All measurements were performed in the 
backscattering geometry using a $50 \times$ objective (numerical aperture 0.75 , working distance $0.37 \mathrm{~mm}$ ), at room temperature and atmospheric pressure. Scans were accumulated to obtain spectra in the wavelength domain $100-3500 \mathrm{~cm}^{-1}$ with a resolution of $1 \mathrm{~cm}^{-1}$. Spectral manipulations were performed with WiRE 3.2 software (Renishaw, Wotton-underEdge, UK).

\subsection{DLS Analysis}

DLS analysis was performed to determine the hydrodynamic diameter (Z-average), PDI and zeta potential values of AgNPs (Malvern Zetasizer Nano-ZS, Malvern Instruments, Malvern, UK). For the hydrodynamic diameter and PDI measurements, the samples were analysed at $25^{\circ} \mathrm{C}$ by DLS at an angle of $90^{\circ}$, using red He/Ne laser at $\lambda=633 \mathrm{~nm}$. Zeta potential was recorded through electrophoretic light scattering at $25^{\circ} \mathrm{C}$.

\subsection{SEM and EDX Analysis}

The experiments were performed with a Quanta 200 scanning electron microscope equipped with an energy dispersive spectrometer (FEI Company, Hillsboro, OR, USA). The samples were fixed on adequate support and operated in low vacuum mode at $20 \mathrm{kV}$. The AgNPs surface was observed under different magnifications with a secondary electron detector (large field detector) while a silicon drift detector was used to obtain elemental information.

\subsection{TEM Analysis}

The samples were examined in the high contrast mode on a Hitachi High-Tech HT7700 transmission electron microscope (Hitachi High-Technologies Corporation, Tokyo, Japan) at $120 \mathrm{kV}$ accelerating voltage. The instrument is equipped with a Bruker EDX detector that allows elemental analysis and a SAED aperture that could be used to collect diffraction patterns directly during the sample inspection. A drop of each colloidal AgNPs solution was placed on a 300-mesh carbon-coated copper grid (Ted Pella) and vacuum-dried at room temperature for $24 \mathrm{~h}$ prior to examination.

\subsection{Antimicrobial Assay}

The antimicrobial activity of AgNPs and bark extracts used for their synthesis was investigated by the disk diffusion method against Gram-positive and Gram-negative bacteria (S. aureus, S. epidermidis, S. pyogenes and E. coli, P. aeruginosa, respectively) and fungi (C. albicans). In brief, microbial inoculum, adjusted to the turbidity of $0.5 \mathrm{McFarland}$ standard, was spread over Mueller-Hinton agar (for bacteria) and potato dextrose agar (for fungus) in sterile Petri plates (diameter $9 \mathrm{~cm}$ ). Sterile paper disks (diameter $6 \mathrm{~mm}$ ), impregnated with equal volumes of colloidal AgNPs solutions and bark extracts $(25 \mu \mathrm{L})$ were placed over medium. The diameters of the inhibition zones were measured after $24 \mathrm{~h}$ incubation at $37{ }^{\circ} \mathrm{C}[4,77]$. Gentamicin $(10 \mu \mathrm{g} /$ disk) and nystatin (100 units/disk) were used as positive controls. Each experiment was performed in triplicate and the results were expressed as mean \pm standard deviation.

\subsection{Cytogenotoxicity Assay}

The cytogenotoxicity of AgNPs and bark extracts was assessed by Allium cepa assay as previously described $[22,71,78]$ with some modifications. High quality equal-sized onion bulbs were purchased from a local market. Their outer scales were removed, and their bottoms were scraped to expose root primordia. Onion bulbs were further placed in $100 \mathrm{~mL}$ jars filled with tap water, only the root primordia being immersed into water. After $24 \mathrm{~h}$, the tap water in the jars was replaced with the same volume of each sample. The root primordia were kept immersed in samples for another $12 \mathrm{~h}$. The control was represented by the onion bulbs immersed in tap water for $36 \mathrm{~h}$. For each sample and control, the root tips of three onions were sampled, the roots from each bulb being processed separately. The roots were initially fixed in ethanol:glacial acetic acid $(3: 1, v / v)$ for $12 \mathrm{~h}$ at $4{ }^{\circ} \mathrm{C}$ and 
then heated for $20 \mathrm{~min}$ in acetic carmine solution $(10 \mathrm{~mL})$ containing ten drops of $1 \mathrm{~N}$ hydrochloric acid. The root tips were cut on a glass slide, covered with a coverslip, and squashed. A number of approximatively 3000 cells per each slide were examined for the mitotic index, mitotic stages and chromosome aberrations using an Optika B-159 microscope $(400 \times$ magnification) coupled with Optikam B5 camera (Image J program) (Optika, Ponteranica Italy). The mitotic index was calculated as the percentage of cells undergoing mitosis of the total number of cells scored. The number of cells in different mitotic stages (prophase, metaphase, anaphase, telophase) was expressed as percentage of the total dividing cells. In the same manner (percentage of the total dividing cells), different types of chromosomal aberrations were also quantified. All experiments were performed in triplicate and the results were expressed as mean \pm standard deviation.

\subsection{Statistical Analysis}

Statistical analyses were performed using SPSS software version 18.0. The paired samples $t$-test was used for comparing the means of any two normally distributed variables.

\section{Conclusions}

In the present study, colloidal phyto-functionalized AgNPs were produced using bark aqueous extracts of Picea abies and Pinus nigra. For both bark extracts, polyphenols were found to be majorly involved in the synthesis and stabilization of AgNPs but ATR-FTIR and Raman spectroscopic data clearly indicated the contribution of other compounds in bark extracts (carbohydrates, proteins). DLS, SEM, TEM and EDX techniques showed that Picea abies and Pinus nigra bark extract derived AgNPs were spherical in shape, crystalline, homogenous, and well dispersed, with mean hydrodynamic diameters below $100 \mathrm{~nm}$ which is a prerequisite for a good antimicrobial activity. Both AgNPs exhibited stronger antibacterial, antifungal, and antimitotic effects than the bark extracts used for their synthesis. Based on these results, future investigations will focus on the development of novel formulations by impregnation of the colloidal AgNPs solutions obtained in the present study into polymeric nanofibers for topical application in infectious and hyperproliferative skin disorders. In addition, both Picea abies and Pinus nigra are used in the lumber industry, the bark being the main waste. The green synthesis of AgNPs could be a potential route for the valorization of bark waste.

Author Contributions: Conceptualization, I.M.; Investigation, I.M., S.V.L., K.S.-W., L.S., P.P., A.G., F.D., E.-L.U., C.M.R., C.E.H., C.L., G.V. and A.D.P.; Methodology, I.M., S.V.L., K.S.-W., L.S., P.P., A.G., F.D., E.-L.U., C.M.R., C.E.H., C.L., G.V. and A.D.P.; Resources, C.N.; Supervision, C.M.R., M.A.C. and A.M.; Validation, I.M.; Writing—original draft, I.M. and A.M.; Writing—review and editing, A.M. All authors have read and agreed to the published version of the manuscript.

Funding: This research received no external funding.

Institutional Review Board Statement: Not applicable.

Informed Consent Statement: Not applicable.

Data Availability Statement: Data supporting reported results are available from the corresponding authors.

Acknowledgments: I.M. gratefully acknowledges Valeria Harabagiu, Petru Poni Institute of Macromolecular Chemistry, Iasi, Romania, for kind support and valuable suggestions.

Conflicts of Interest: The authors declare no conflict of interest.

Sample Availability: Samples of the compounds are available from the authors. 


\section{Abbreviation}

AgNPs
ATR-FTIR
DLS
EDX
HPLC-DAD-ESI-Q-TOF-MS/MS

$\mathrm{MF}$

PDI

MRSA

MSSA

SAED

SEM

TEM

$\mathrm{T}_{\mathrm{R}}$

Z-average
Silver nanoparticles

Attenuated total reflection Fourier-transform infrared

Dynamic light scattering

Energy dispersive $\mathrm{X}$-ray analysis

High-performance liquid chromatography with diode array detection coupled to electrospray ionization quadrupole timeof-flight tandem mass spectrometry

Molecular formula

Polydispersity index

Methicillin-resistant Staphylococcus aureus

Methicillin-susceptible Staphylococcus aureus

Selected area electron diffraction

Scanning electron microscopy

Transmission electron microscopy

Retention time

Hydrodynamic diameter

\section{References}

1. Islam, M.A.; Jacob, M.V.; Antunes, E. A critical review on silver nanoparticles: From synthesis and applications to its mitigation through low-cost adsorption by biochar. J. Environ. Manag. 2021, 281, 111918. [CrossRef] [PubMed]

2. Beyene, H.D.; Werkneh, A.A.; Bezabh, H.K. Synthesis paradigm and applications of silver nanoparticles (AgNPs), a review. Sustain. Mater. Technol. 2017, 13, 18-23. [CrossRef]

3. Rajan, R.; Chandran, K.; Harper, S.L.; Yun, S.-I.; Kalaichelvan, P.T. Plant extract synthesized nanoparticles: An ongoing source of novel biocompatible materials. Ind. Crops Prod. 2015, 70, 356-373. [CrossRef]

4. Biao, L.; Tan, S.; Zhang, X.; Gao, J.; Liu, Z.; Fu, Y. Synthesis and characterization of proanthocyanidins-functionalized Ag nanoparticles. Colloids Surf. B Biointerfaces 2018, 169, 438-443. [CrossRef]

5. Benedec, D.; Oniga, I.; Cuibus, F.; Sevastre, B.; Stiufiuc, G.; Duma, M.; Hanganu, D.; Iacovita, C.; Stiufiuc, R.; Lucaciu, C.M. Origanum vulgare mediated green synthesis of biocompatible gold nanoparticles simultaneously possessing plasmonic, antioxidant and antimicrobial properties. Int. J. Nanomed. 2018, 13, 1041-1058. [CrossRef] [PubMed]

6. Koduru, J.R.; Kailasa, S.K.; Bhamore, J.R.; Kim, K.-H.; Dutta, T.; Vellingiri, K. Phytochemical-assisted synthetic approaches for silver nanoparticles antimicrobial applications: A review. Adv. Colloid Interface Sci. 2018, 256, 326-339. [CrossRef] [PubMed]

7. Alkhalaf, M.I.; Hussein, R.H.; Hamza, A. Green synthesis of silver nanoparticles by Nigella sativa extract alleviates diabetic neuropathy through anti-inflammatory and antioxidant effects. Saudi J. Biol. Sci. 2020, 27, 2410-2419. [CrossRef]

8. Ravindran, J.; Arumugasamy, V.; Baskaran, A. Wound healing effect of silver nanoparticles from Tridax procumbens leaf extracts on Pangasius hypophthalmus. Wound Med. 2019, 27, 100170. [CrossRef]

9. Asghar, M.A.; Yousuf, R.I.; Shoaib, M.H.; Asghar, M.A. Antibacterial, anticoagulant and cytotoxic evaluation of biocompatible nanocomposite of chitosan loaded green synthesized bioinspired silver nanoparticles. Int. J. Biol. Macromol. 2020, 160, 934-943. [CrossRef]

10. Ali, M.S.; Anuradha, V.; Yogananth, N.; Krishnakumar, S. Heart and liver regeneration in zebrafish using silver nanoparticle synthesized from Turbinaria conoides-In vivo. Biocatal. Agric. Biotechnol. 2019, 17, 104-109. [CrossRef]

11. Jini, D.; Sharmila, S. Green synthesis of silver nanoparticles from Allium cepa and its in vitro antidiabetic activity. Mater. Today Proc. 2020, 22, 432-438. [CrossRef]

12. Anbukkarasi, M.; Thomas, P.A.; Teresa, P.A.; Anand, T.; Geraldine, P. Comparison of the efficacy of a Tabernaemontana divaricata extract and of biosynthesized silver nanoparticles in preventing cataract formation in an in vivo system of selenite-induced cataractogenesis. Biocatal. Agric. Biotechnol. 2020, 23, 101475. [CrossRef]

13. Radwan, R.A.; El-Sherif, Y.A.; Salama, M.M. A novel biochemical study of anti-ageing potential of Eucalyptus camaldulensis bark waste standardized extract and silver nanoparticles. Colloids Surf. B Biointerfaces 2020, 191, 111004. [CrossRef] [PubMed]

14. Fedorov, V.S.; Ryazanova, T.V. Bark of Siberian conifers: Composition, use, and processing to extract tannin. Forests 2021, $12,1043$. [CrossRef]

15. Luca, S.V.; Bujor, A.; Miron, A.; Aprotosoaie, A.C.; Skalicka-Woźniak, K.; Trifan, A. Preparative separation and bioactivity of oligomeric proanthocyanidins. Phytochem. Rev. 2020, 19, 1093-1140. [CrossRef]

16. Mármol, I.; Quero, J.; Jiménez-Moreno, N.; Rodríguez-Yoldi, M.J.; Ancín-Azpilicueta, C. A systematic review of the potential uses of pine bark in food industry and health care. Trends Food Sci. Technol. 2019, 88, 558-566. [CrossRef]

17. Mekinić, I.G.; Skroza, D.; Ljubenkov, I.; Katalinić, V. Insight into the presence of stilbenes in medicinal plants traditionally used in Croatian folk medicine. Nat. Prod. Commun. 2016, 11, 833-835. [CrossRef] [PubMed]

18. El Khawand, T.; Courtois, A.; Valls, J.; Richard, T.; Krisa, S. A review of dietary stilbenes: Sources and bioavailability. Phytochem. Rev. 2018, 17, 1007-1029. [CrossRef] 
19. Das, A.; Baidya, R.; Chakraborty, T.; Samanta, A.K.; Roy, S. Pharmacological basis and new insights of taxifolin: A comprehensive review. Biomed. Pharmacother. 2021, 142, 112004. [CrossRef] [PubMed]

20. Burlacu, E.; Tanase, C.; Coman, N.-A.; Berta, L. A review of bark-extract-mediated green synthesis of metallic nanoparticles and their applications. Molecules 2019, 24, 4354. [CrossRef]

21. Bhardwaj, K.; Dhanjal, D.S.; Sharma, A.; Nepovimova, E.; Kalia, A.; Thakur, S.; Bhardwaj, S.; Chopra, C.; Singh, R.; Verma, R.; et al. Conifer-derived metallic nanoparticles: Green synthesis and biological applications. Int. J. Mol. Sci. 2020, 21, 9028. [CrossRef]

22. Fierascu, I.; Georgiev, M.I.; Ortan, A.; Fierascu, R.C.; Avramescu, S.M.; Ionescu, D.; Sutan, A.; Brinzan, A.; Ditu, L.M. Phytomediated metallic nano-architectures via Melissa officinalis L.: Synthesis, characterization and biological properties. Sci. Rep. 2017, 7, 12428. [CrossRef]

23. Zuorro, A.; Iannone, A.; Natali, S.; Lavecchia, R. Green synthesis of silver nanoparticles using bilberry and red currant waste extracts. Processes 2019, 7, 193. [CrossRef]

24. Bujor, A.; Miron, A.; Luca, S.V.; Skalicka-Woźniak, K.; Silion, M.; Trifan, A.; Girard, C.; Demougeot, C.; Totoson, P. Vasorelaxant effects of Crataegus pentagyna: Links with arginase inhibition and phenolic profile. J. Ethnopharmacol. 2020, 252, 112559. [CrossRef] [PubMed]

25. Bujor, A.; Miron, A.; Luca, S.V.; Skalicka-Woźniak, K.; Silion, M.; Ancuceanu, R.; Dinu, M.; Girard, C.; Demougeot, C.; Totoson, P. Metabolite profiling, arginase inhibition and vasorelaxant activity of Cornus mas, Sorbus aucuparia and Viburnum opulus fruit extracts. Food Chem. Toxicol. 2019, 133, 110764. [CrossRef]

26. Olennikov, D.N.; Penzina, T.A. 2-Methoxy-3,4-dihydroxybenzoic acid and other compounds from Ramaria aurea and Clavariadelphus ligula. Chem. Nat. Compd. 2014, 50, 391-393. [CrossRef]

27. Parada, F.; Krajewski, D.; Herderich, M.; Duque, C.; Schreier, P. 3, 4-Dimethoxyphenyl $\beta$-D-glucopyranoside from piňuela (Bromelia plumieri Kartens) fruit. Nat. Prod. Lett. 1995, 7, 69-72. [CrossRef]

28. Taira, J.; Toyoshima, R.; Ameku, N.; Iguchi, A.; Tamaki, Y. Vanillin production by biotransformation of phenolic compounds in fungus, Aspergillus luchuensis. AMP Expr. 2018, 8, 40. [CrossRef]

29. Ralph, J.; Hatfield, R.D. Pyrolysis-GC-MS characterization of forage materials. J. Agric. Food Chem. 1991, 39, 1426-1437. [CrossRef]

30. Pan, H.; Lundgren, L.N. Phenolics from inner bark of Pinus sylvestris. Phytochemistry 1996, 42, 1185-1189. [CrossRef]

31. Luca, S.V.; Miron, A.; Aprotosoaie, A.C.; Mihai, C.-T.; Vochita, G.; Gherghel, D.; Ciocarlan, N.; Skalicka-Woźniak, K. HPLC-DADESI-Q-TOF-MS/MS profiling of Verbascum ovalifolium Donn ex Sims and evaluation of its antioxidant and cytogenotoxic activities. Phytochem. Anal. 2019, 30, 34-45. [CrossRef]

32. Cretu, E.; Karonen, M.; Salminen, J.-P.; Mircea, C.; Trifan, A.; Charalambous, C.; Constantinou, A.I.; Miron, A. In vitro study on the antioxidant activity of a polyphenol-rich extract from Pinus brutia bark and its fractions. J. Med. Food 2013, 16, 984-991. [CrossRef] [PubMed]

33. Karar, M.G.E.; Kuhnert, N. UPLC-ESI-Q-TOF-MS/MS characterization of phenolics from Crataegus monogyna and Crataegus laevigata (Hawthorn) leaves, fruits and their herbal derived drops (Crataegutt Tropfen). J. Chem. Biol. Ther. 2015, 1, 102. [CrossRef]

34. Yang, C.-J.; Wang, Z.-B.; Mi, Y.-Y.; Gao, M.-J.; Lv, J.-N.; Meng, Y.-H.; Yang, B.-Y.; Kuang, H.-X. UHPLC-MS/MS determination, pharmacokinetic, and bioavailability study of taxifolin in rat plasma after oral administration of its nanodispersion. Molecules 2016, 21, 494. [CrossRef] [PubMed]

35. Bellés, J.M.; López-Gresa, M.P.; Fayos, J.; Pallás, V.; Rodrigo, I.; Conejero, V. Induction of cinnamate-4-hydroxylase and phenylpropanoids in virus-infected cucumber and melon plants. Plant Sci. 2008, 174, 524-533. [CrossRef]

36. Abu-Reidah, I.M.; Arráez-Román, D.; Segura-Carretero, A.; Fernández-Gutiérrez, A. Profiling of phenolic and other polar constituents from hydro-methanolic extract of watermelon (Citrullus lanatus) by means of accurate-mass spectrometry (HPLCESI-QTOF-MS). Food Res. Int. 2013, 51, 354-362. [CrossRef]

37. Shen, Y.; Kojima, Y.; Terezawa, M. Four glucosides of $p$-hydroxyphenyl derivatives from birch leaves. J. Wood Sci. 1999, 45, 332-336. [CrossRef]

38. Gabaston, J.; Richard, T.; Biais, B.; Waffo-Teguo, P.; Pedrot, E.; Jourdes, M.; Corio-Costet, M.-F.; Mérillon, J.-M. Stilbenes from common spruce (Picea abies) bark as natural antifungal agent against downy mildew (Plasmopara viticola). Ind. Crops Prod. 2017, 103, 267-273. [CrossRef]

39. Francezon, N.; Meda, N.R.; Stevanovic, T. Optimization of bioactive polyphenols extraction from Picea mariana bark. Molecules 2017, 22, 2118. [CrossRef]

40. Karthika, V.; Arumugam, A.; Gopinath, K.; Kaleeswarran, P.; Govindarajan, M.; Alharbi, N.S.; Kadaikunnan, S.; Khaled, J.M.; Benelli, G. Guazuma ulmifolia bark-synthesized Ag, Au and Ag/Au alloy nanoparticles: Photocatalytic potential, DNA/protein interactions, anticancer activity and toxicity against 14 species of microbial pathogens. J. Photochem. Photobiol. B 2017, 167, 189-199. [CrossRef]

41. Saber, M.M.; Mirtajani, S.B.; Karimzadeh, K. Green synthesis of silver nanoparticles using Trapa natans extract and their anticancer activity against A431 human skin cancer cells. J. Drug Deliv. Sci. Technol. 2018, 47, 375-379. [CrossRef]

42. Soris, P.T.; Beulah, G.G.P.; Doss, A.; Mohan, V.R. Croton sparsiflorus whole plant extract mediated biosynthesis of metallic silver nanoparticles and their antibacterial activity. J. Drug Deliv. Ther. 2018, 8, 91-97. [CrossRef]

43. Jebril, S.; Jenana, R.K.B.; Dridi, C. Green synthesis of silver nanoparticles using Melia azedarach leaf extract and their antifungal activities: In vitro and in vivo. Mater. Chem. Phys. 2020, 248, 122898. [CrossRef] 
44. Taruna; Kaushal, J.; Bhatti, J.; Kumar, P. Green synthesis and physico-chemical study of silver nanoparticles extracted from a natural source Luffa acutangula. J. Mol. Liq. 2016, 224, 991-998. [CrossRef]

45. Adib, A.M.; Jamaludin, F.; Kiong, L.S.; Hashim, N.; Abdullah, Z. Two-dimensional correlation infrared spectroscopy applied to analyzing and identifying the extracts of Baeckea frutescens medicinal materials. J. Pharm. Biomed. Anal. 2014, 96, 104-110. [CrossRef] [PubMed]

46. Jiamboonsri, P.; Wanwong, S. Photoassisted synthesis of silver nanoparticles using riceberry rice extract and their antibacterial application. J. Nanomater. 2021, 2021, 5598924. [CrossRef]

47. Coseri, S.; Spatareanu, A.; Sacarescu, L.; Rimbu, C.; Suteu, D.; Spirk, S.; Harabagiu, V. Green synthesis of the silver nanoparticles mediated by pullulan and 6-carboxypullulan. Carbohydr. Polym. 2015, 116, 9-17. [CrossRef]

48. Patra, S.; Mukherjee, S.; Barui, A.K.; Ganguly, A. Green synthesis, characterization of gold and silver nanoparticles and their potential application for cancer therapeutics. Mat. Sci. Eng. C Mater. Biol. Appl. 2015, 53, 298-309. [CrossRef]

49. Harshiny, M.; Matheswaran, M.; Arthanareeswaran, G.; Kumaran, S.; Rajasree, S. Enhancement of antibacterial properties of silver nanoparticles-ceftriaxone conjugate through Mukia maderaspatana leaf extract mediated synthesis. Ecotoxicol. Environ. Saf. 2015, 121, 135-141. [CrossRef] [PubMed]

50. Katas, H.; Lim, C.S.; Nor Azlan, A.Y.H.; Bunag, F.; Mh Busra, M.F. Antibacterial activity of biosynthesized gold nanoparticles using biomolecules from Lignosus rhinocerotis and chitosan. Saudi Pharm. J. 2019, 27, 283-292. [CrossRef] [PubMed]

51. Konai, N.; Raidandi, D.; Pizzi, A.; Meva'a, L. Characterization of Ficus sycomorus tannin using ATR-FT MIR, MALDI-TOF MS and 13 C NMR methods. Eur. J. Wood Prod. 2017, 75, 807-815. [CrossRef]

52. Marslin, G.; Siram, K.; Maqbool, Q.; Selvakesavan, R.K.; Kruszka, D.; Kachlicki, P.; Franklin, G. Secondary metabolites in the green synthesis of metallic nanoparticles. Materials 2018, 11, 940. [CrossRef] [PubMed]

53. Katta, V.K.M.; Dubey, R.S. Green synthesis of silver nanoparticles using Tagetes erecta plant and investigation of their structural, optical, chemical and morphological properties. Mater. Today Proc. 2021, 45, 794-798. [CrossRef]

54. Tanase, C.; Berta, L.; Coman, N.A.; Rosca, I.; Man, A.; Toma, F.; Mocan, A.; Nicolescu, A.; Jakab-Farkas, L.; Biró, D.; et al Antibacterial and antioxidant potential of silver nanoparticles biosynthesized using the spruce bark extract. Nanomaterials 2019, 9, 1541. [CrossRef]

55. Filip, G.A.; Florea, A.; Olteanu, D.; Clichici, S.; David, L.; Moldovan, B.; Cenariu, M.; Scrobota, I.; Potara, M.; Baldea, I. Biosynthesis of silver nanoparticles using Sambucus nigra L. fruit extract for targeting cell death in oral dysplastic cells. Mat. Sci. Eng. C Mater. Biol. Appl. 2021, 123, 111974. [CrossRef] [PubMed]

56. Logaranjan, K.; Raiza, A.J.; Gopinath, S.C.B.; Chen, Y.; Pandian, K. Shape- and size-controlled synthesis of silver nanoparticles using Aloe vera plant extract and their antimicrobial activity. Nanoscale Res. Lett. 2016, 11, 520. [CrossRef]

57. Kora, A.J.; Arunachalam, J. Green fabrication of silver nanoparticles by gum tragacanth (Astragalus gummifer): A dual functional reductant and stabilizer. J. Nanomater. 2012, 2012, 869765. [CrossRef]

58. Dumitriu, R.P.; Nita, L.E.; Sacarescu, L.; Vasilescu, D.S. Preparation of silver nanoparticle dispersion by a green synthesis method. UPB Sci. Bull. Ser. B 2015, 77, 81-90.

59. Nasiriboroumand, M.; Montazer, M.; Barani, H. Preparation and characterization of biocompatible silver nanoparticles using pomegranate peel extract. J. Photochem. Photobiol. B 2018, 179, 98-104. [CrossRef]

60. Suriyakalaa, U.; Antony, J.J.; Suganya, S.; Siva, D.; Sukirtha, R.; Kamalakkannan, S.; Pichiah, P.B.T.; Achiraman, S. Hepatocurative activity of biosynthesized silver nanoparticles fabricated using Andrographis paniculata. Colloids Surf. B Biointerfaces 2013, 102, 189-194. [CrossRef]

61. Sudha, A.; Jeyakanthan, J.; Srinivasan, P. Green synthesis of silver nanoparticles using Lippia nodiflora aerial extract and evaluation of their antioxidant, antibacterial and cytotoxic effects. Resour. Effic. Technol. 2017, 3, 506-515. [CrossRef]

62. Iravani, S.; Zolfaghari, B. Green synthesis of silver nanoparticles using Pinus eldarica bark extract. BioMed Res. Int. 2013, 639725. [CrossRef]

63. Tanase, C.; Berta, L.; Mare, A.; Man, A.; Talmaciu, A.I.; Rosca, I.; Mircia, E.; Volf, I.; Popa, V.I. Biosynthesis of silver nanoparticles using aqueous bark extract of Picea abies L. and their antibacterial activity. Eur. J. Wood Wood Prod. 2020, 78, 281-291. [CrossRef]

64. Roy, A.; Bulut, O.; Some, S.; Mandal, A.K.; Yilmaz, M.D. Green synthesis of silver nanoparticles: Biomolecule-nanoparticle organizations targeting antimicrobial activity. RSC Adv. 2019, 9, 2673. [CrossRef]

65. Franci, G.; Falanga, A.; Galdiero, S.; Palomba, L.; Rai, M.; Morelli, G.; Galdiero, M. Silver nanoparticles as potential antibacterial agents. Molecules 2015, 20, 8856-8874. [CrossRef]

66. Renuka, R.; Renuka Devi, K.; Sivakami, M.; Thilagavathi, T.; Uthrakumar, R.; Kaviyarasu, K. Biosynthesis of silver nanoparticles using Phyllanthus emblica fruit extract for antimicrobial application. Biocatal. Agric. Biotechnol. 2020, 24, 101567. [CrossRef]

67. Apetrei, C.L.; Tuchilus, C.; Aprotosoaie, A.C.; Oprea, A.; Malterud, K.E.; Miron, A. Chemical, antioxidant and antimicrobial investigations of Pinus cembra L. bark and needles. Molecules 2011, 16, 7773-7788. [CrossRef]

68. Velidandi, A.; Dahariya, S.; Pabbathi, N.P.P.; Kalivarathan, D.; Baadhe, R.R. A review on synthesis, applications, toxicity, risk assessments and limitations of plant extracts synthesized silver nanoparticles. NanoWorld J. 2020, 6, 35-60. [CrossRef]

69. Debnath, P.; Mondal, A.; Hajra, A.; Das, C.; Mondal, N.K. Cytogenetic effects of silver and gold nanoparticles on Allium cepa roots. J. Genet. Eng. Biotechnol. 2018, 16, 519-526. [CrossRef] [PubMed]

70. Kumari, M.; Mukherjee, A.; Chandrasekaran, N. Genotoxicity of silver nanoparticles in Allium cepa. Sci. Total Environ. 2009, 407, 5243-5346. [CrossRef] [PubMed] 
71. Yekeen, T.A.; Azeez, M.A.; Lateef, A.; Asafa, T.B.; Oladipo, I.C.; Badmus, J.A.; Adejumo, S.A.; Ajibola, A.A. Cytogenotoxicity potentials of cocoa pod and bean-mediated green synthesized silver nanoparticles on Allium cepa cells. Caryologia 2017, 70, 366-377. [CrossRef]

72. Raju, R.; Paul, A.G.; Aguilor, U.P.; Capili, J.T. The effect of induced acid rain; Allium cepa chromosomal aberration assay. Sch. Acad. J. Biosci. 2021, 9, 89-97. [CrossRef]

73. Sabeen, M.; Mahmood, Q.; Bhatti, Z.A.; Faridullah; Irshad, M.; Bilal, M.; Hayat, M.T.; Irshad, U.; Akbar, T.A.; Arslan, M.; et al. Allium cepa assay based comparative study of selected vegetables and the chromosomal aberrations due to heavy metal accumulation. Saudi J. Biol. Sci. 2020, 27, 1368-1375. [CrossRef]

74. Qa'dan, F.; Petereit, F.; Mansoor, K.; Nahrsted, A. Antioxidant oligomeric proanthocyanidins from Cistus salvifolius. Nat. Prod. Res. 2006, 20, 1216-1224. [CrossRef] [PubMed]

75. Kalishwaralal, K.; BarathManiKanth, S.; Pandian, S.R.K.; Deepak, V.; Gurunathan, S. Silver nanoparticles impede the biofilm formation by Pseudomonas aeruginosa and Staphylococcus epidermidis. Colloids Surf. B Biointerfaces 2010, 79, 340-344. [CrossRef] [PubMed]

76. Alshehri, A.A.; Malik, M.A. Phytomediated photo-induced green synthesis of silver nanoparticles using Matricaria chamomilla L. and its catalytic activity against rhodamine B. Biomolecules 2020, 10, 1604. [CrossRef]

77. Tripathi, D.; Modi, A.; Narayan, G.; Rai, S.P. Green and cost effecti ve synthesis of silver nanoparticles from endangered medicinal plant Withania coagulans and their potential biomedical properties. Mater. Sci. Eng. C Mater. Biol. Appl. 2019, 100, 152-164. [CrossRef]

78. Chandraker, S.K.; Lal, M.; Dhruve, P.; Singh, R.P.; Shukla, R. Cytotoxic, antimitotic, DNA binding, photocatalytic, $\mathrm{H}_{2} \mathrm{O}_{2}$ sensing, and antioxidant properties of biofabricated silver nanoparticles using leaf extract of Bryophyllum pinnatum (Lam.) Oken. Front. Mol. Biosci. 2021, 7, 593040. [CrossRef] 